DOE $/ E S-0003 / 1$

DE83 $01505 \hat{C}_{3}$

\title{
A HISTORY OF THE ATOMIC ENERGY COMMISSION
}

\author{
by: \\ Alice L. Buck
}

\section{July 1983}

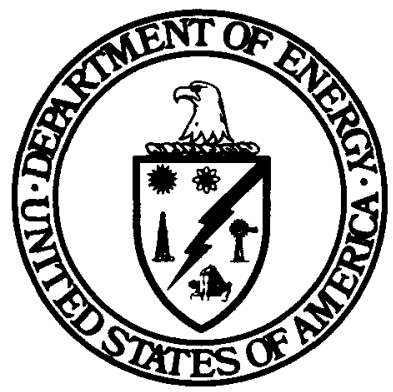

\section{DISCLAIMER}

This report was prepared as an account of work sponsored by an agency of the United States Government. Neither the United States Government nor any agency thereof, nor any of their employees, makes any warranty, express or implied, or assumes any legal liability or responsibility for the accuracy, completeness, or usefulness of any information, apparatus, product, or process disclosed, or represents that its use would not infringe privately owned rights. Reference herein to any specific commercial product, process, or service by trade name, trademark, manufacturer, or otherwise does not necessarily constitute or imply its endorsement, recommendation, or favoring by the United States Government or any agency thereof. The views and opinions of authors expressed herein do not necessarily state or reflect those of the United States Government or any agency thereof.

\section{U.S. Department of Energy Assistant Secretary, Management and Administration Office of The Executive Secretariat History Division




\section{DISCLAIMER}

This report was prepared as an account of work sponsored by an agency of the United States Government. Neither the United States Government nor any agency Thereof, nor any of their employees, makes any warranty, express or implied, or assumes any legal liability or responsibility for the accuracy, completeness, or usefulness of any information, apparatus, product, or process disclosed, or represents that its use would not infringe privately owned rights. Reference herein to any specific commercial product, process, or service by trade name, trademark, manufacturer, or otherwise does not necessarily constitute or imply its endorsement, recommendation, or favoring by the United States Government or any agency thereof. The views and opinions of authors expressed herein do not necessarily state or reflect those of the United States Government or any agency thereof. 


\section{DISCLAIMER}

Portions of this document may be illegible in electronic image products. Images are produced from the best available original document. 
This pamphlet is part of a Series prepared by the History Division on the "Institutional Origins of the Department of Energy." The Series includes the following pamphlets:

Energy History Chronology from World War II to the Present

The United States Department of Energy: A History (Draft)

The U.S. Atomic Energy Commission

The Federal Energy Administration

The History of the Energy Research and Development Administration

The Office of Military Application

The Office of Oil and Natural Cas Supply Development 
To W.B. McCool, Secretary to the Commission, a dedicated public official whose imaginative leadership and foresight in administering the Office of the Secretary; whose initiative in establishing and supporting within his staff a history program for the preparation of an official history of the Commission; and whose skill in developing a highly sucessful management program for bringing outstanding young men and women into the federal service, all contributed to making the Executive Secretariat a model for administering complex and technical programs. 


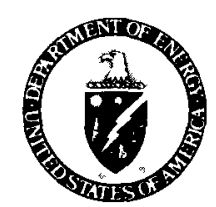

\section{Department of Energy Washington, D.C. 20585}

The Department of Energy Orqanization Act of 1977 brought together for the first time in one department most of the Federal Government's energy programs. With these programs came a score of organizational entities, each with its own history and traditions, from a dozen departments and independent agencies. The History Division has prepared a series of pamphlets on the Institutional Origins of the Department of Fnergy. Fach pamphlet explains the history, qoals, and achievements of a predecessor agency of the Department of Enerqy.

One purpose of the series is to provide a handv reference work which traces the organizational antecedents of the major programs and offices of the Department. In several instances the search for materials has resulted in the preservation of valuable historical records that otherwise might have been lost or destroyed. The preservation of these records in the Departmental Archives is an important first step in collecting materials for a comprehensive history of the role of the Federal Government in both stimulating and regulating the development of energy resources and systems in the United States since World War II.

This pamphlet traces the history of the Atomic Fnergy Commission's twenty-eight year stewardship of the Nation's nuclear energy program, from the signing of the Atomic Energy Act on August 1, 1946 to the signing of the Enerqy Reorganization Act on October 11, 1974. The Commission's early concentration on the militarv atom produced sophisticated nuclear weapons for the ration's defense and made possible the creation of a fleet of nuclear submarines and surface ships. Extensive research in the nuclear sciences resulted in the widespread application of nuclear technology for scientific, medical and industrial purposes, while the passage of the Atomic Fnergy Act of 1954 made possible the development of a nuclear industry, and enabled the United states to share the new technology with other nations.

Alice L. Buck is a trained historian working in the History Division. Although whenever possible she has checked her work with appropriate offices within the Department, the author takes full responsibility for the content and conclusions of the study.

It is our hope that this pamphlet will prove useful both to Departmental personnel and the public.

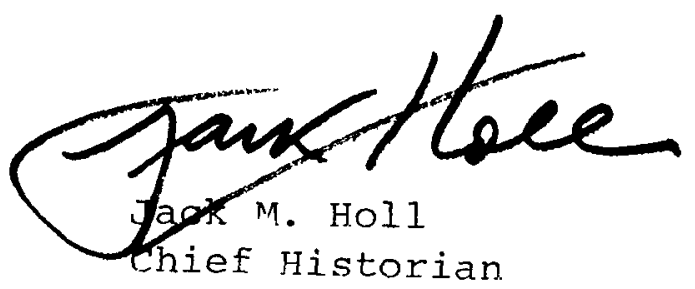




\section{Table of Contents}

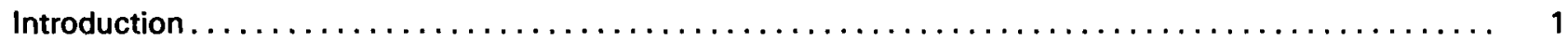

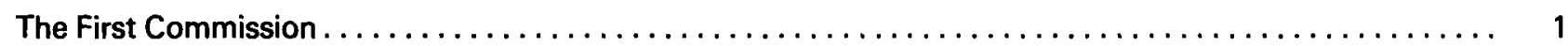

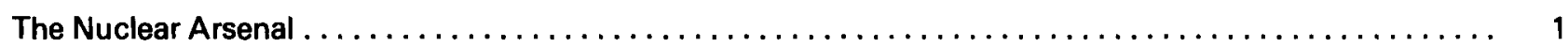

Production Expansion. . . . . . . . . . . . . . . . . . . . . . . .

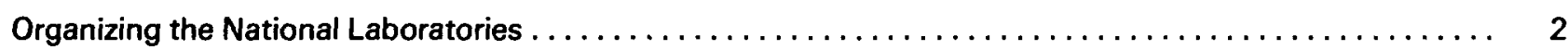

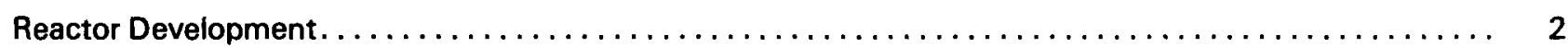

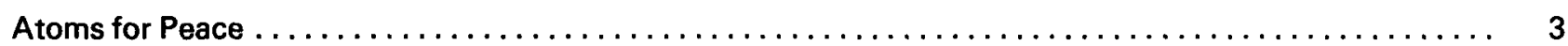

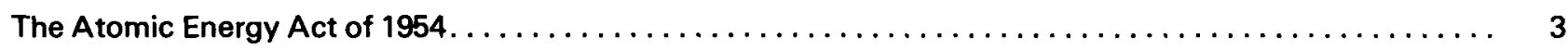

The Five Year Plan. . . . . . . . . . . . . . . . . . . . . .

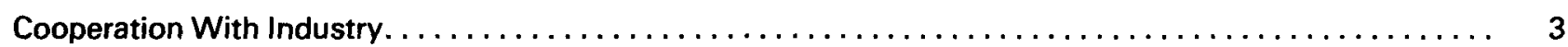

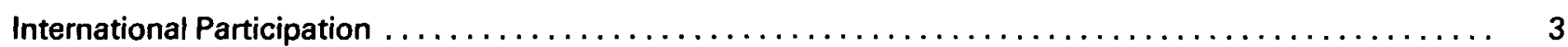

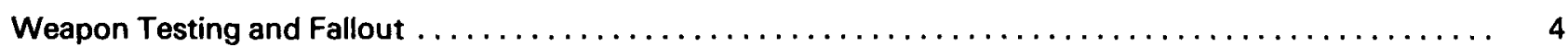

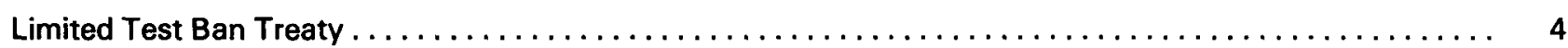

Civilian Power: The Proliferation of the Peaceful Atom in the Sixties $\ldots \ldots \ldots \ldots \ldots \ldots \ldots \ldots \ldots \ldots \ldots$

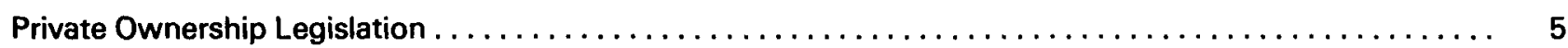

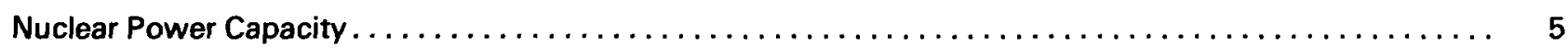

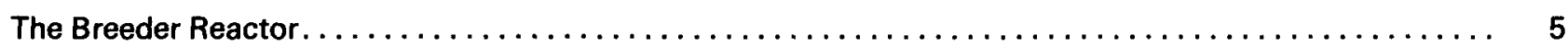

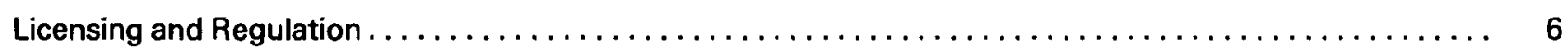

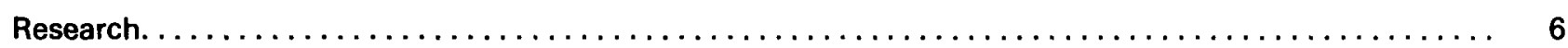

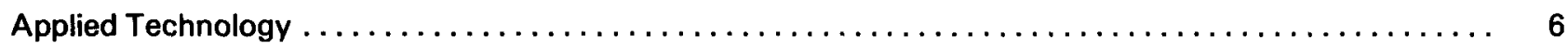

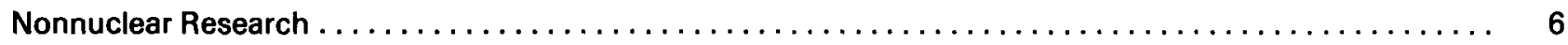

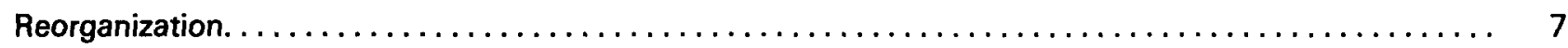

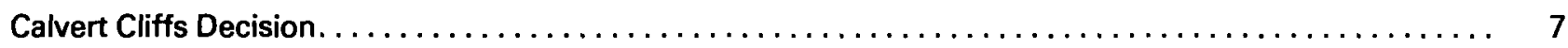

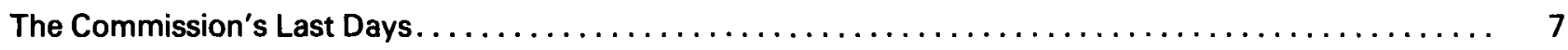

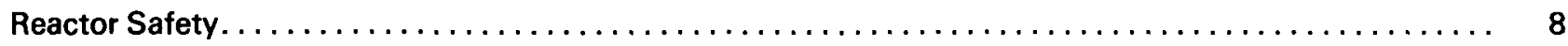

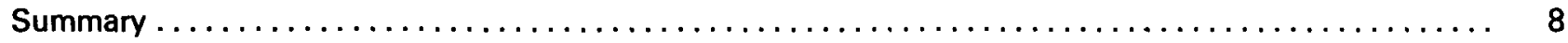

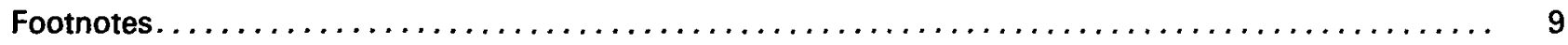

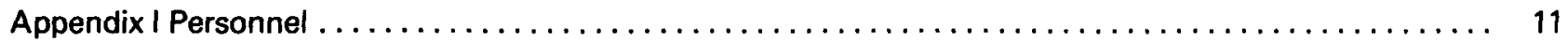

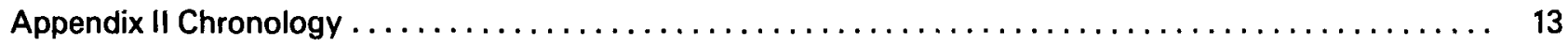

Appendix III Laboratories and Production Facilities $\ldots \ldots \ldots \ldots \ldots \ldots \ldots \ldots \ldots \ldots \ldots \ldots \ldots \ldots \ldots$

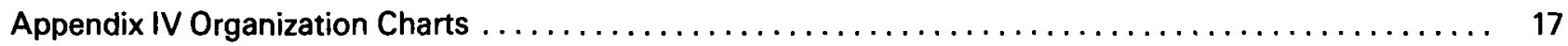

Appendix $V$ Nuclear Detonations and Early Stockpile Data $\ldots \ldots \ldots \ldots \ldots \ldots \ldots \ldots \ldots \ldots \ldots \ldots$

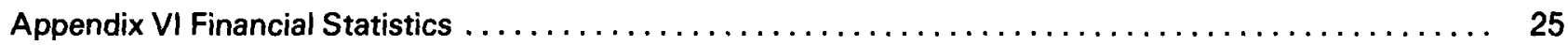

Appendix VII Institutional Origins of the Department of Energy $\ldots \ldots \ldots \ldots \ldots \ldots \ldots \ldots \ldots \ldots$ 


\section{Introduction}

Almost a year after World War II ended, Congress established the United States Atomic Energy Commission to foster and control the peacetime development of atomic science and technology. Reflecting America's postwar optimism, Congress declared that atomic energy should be employed not only in the Nation's defense, but also to promote world peace, improve the public welfare, and strengthen free competition in private enterprise. After long months of intensive debate among politicians, military planners and atomic scientists, President Harry S. Truman confirmed the civilian control of atomic energy by signing the Atomic Energy Act on August 1, 1946.(1)

The provisions of the new Act bore the imprint of the American plan for international control presented to the United Nations Atomic Energy Commission two months earlier by U.S. Representative Bernard Baruch. Although the Baruch proposal for a multinational corporation to develop the peaceful uses of atomic energy failed to win the necessary Soviet support, the concept of combining development, production, and control in one agency found acceptance in the domestic legislation creating the United States Atomic Energy Commission.(2)

Congress gave the new civilian Commission extraordinary power and independence to carry out its awesome responsibilities. Five Commissioners appointed by the President would exercise authority for the operation of the Commission, while a general manager, also appointed by the President, would serve as chief executive officer. To provide the Commission exceptional freedom in hiring scientists and professionals, Commission employees would be exempt from the Civil Service system. Because of the need for great security, all production facilities and nuclear reactors would be government-owned, while all technical information and research results would be under Commission control, and thereby excluded from the normal application of the patent system.

In addition, the Act provided for three major advisory committees: a Congressional Joint Committee on Atomic Energy, a Military Liaison Committee, and a General Advisory Committee of outstanding scientists.(3)

\section{The First Commission}

On January 1, 1947, the fledgling Atomic Energy Commission took over from the Manhattan Engineer District the massive research and production facilities built during World War II to develop the atomic bomb. The facilities were the product of an extraordinary mission accomplished in three years in almost complete secrecy. Under the direction of General Leslie R. Groves of the Army Corps of Engineers, the laboratory experiments of Enrico Fermi and other American and European scientists had been transformed into operating plants capable of producing a military weapon of devastating power. When the atomic bomb was dropped on Hiroshima on August 6, 1945, and three days later on Nagasaki, not only was a long and costly war brought to an end, but the world also became aware of a completely new and largely unexpected technology.(4)

As the first chairman of the agency created to control the peacetime development of the new technology, President Harry Truman appointed David E. Lilienthal, a lawyer and former head of the Tennessee Valley Authority. During the preceding year, Lilienthal and Under Secretary of State Dean Acheson had co-authored the well-known Acheson-Lilienthal report which had formed the basis for the American plan for international control of atomic energy. Serving with Lilienthal on the Commission were Sumner T. Pike, a businessman from New England, William T. Waymack, a farmer and newspaper editor from lowa, Lewis L. Strauss, a conservative banker and reserve admiral, and Robert F. Bacher, a physicist from Los Alamos and the only scientist on the Commission. Carroll L. Wilson, a young engineer who had helped Vannevar Bush organize the National Defense Research Committee during the war, was appointed general manager. Two floors of the New War Department Building in Washington provided a temporary home for the Commission. A few months later more permanent headquarters were found at 19th and Constitution Avenue, N.W., in the former wartime offices of the Joint Chiefs of Staff.

The new Commission faced a challenging future. World War II was quickly followed by an uneasy international situation commonly referred to as the Cold War, and Lilienthal and his colleagues soon found that most of the Com. mission's resources had to be devoted to weapon development and production. The requirements of national defense thus quickly obscured their original goal of developing the full potential of the peaceful atom. For two decades military-related programs would command the lion's share of the Commission's time and the major portion of the budget. (5)

\section{The Nuclear Arsenal}

To meet the Nation's expanding requirements for fissionable material the Commission set about refurbishing the production and research facilities built during the war. A major overhaul of the original reactors and two new plutonium reactors were authorized for the Hanford, Washington plant. Oak Ridge was scheduled for an addition to the existing K-25 plant and a third gaseous diffusion plant for the production of uranium 235. The Commission decided to adopt the Army's practice of hiring private corporations to operate plants and laboratories, thereby extending into peacetime the contractor system previously used by the Government only in times of national emergency.

The first test of new weapons was conducted at Enewetak Atoll in April and May 1948. Operation Sandstone explored weapon designs and tested a new fission weapon to replace the clumsy tailor-made models used during World War II. By 1948 the Commission had both gun-type and implosion-type non-nuclear and nuclear components in stockpile and was well on the way toward producing an arsenal of nuclear weapons.

In early September 1949 a special Air Force unit detected a large radioactive mass over the Pacific, indicating that the Soviet Union had successfully detonated a nuclear device. The Soviet detonation not only ended the United States' monoploy of nuclear weapons, but also had an immediate effect on the Commission's planned expansion program. During the prolonged debate which followed the announcement of the Soviet event, Commissioner Lewis L. Strauss, supported by fellow Commis- 
sioner Gordon Dean, urged the Commission to take a "quantum jump" by developing a thermonuclear weapon. Strong support for the Strauss' position came from the Congressional Joint Committee on Atomic Energy, and from scientists such as Edward Teller, Luis W. Alverez, and Ernest $O$. Lawrence, who agreed that the development of the superbomb was absolutely essential to the security of the United States. The members of the General Advisory Committee, however, while concurring in the need for giving high priority to the development of atomic weapons for tactical purposes, recommended against an all-out effort to develop a hydrogen bomb. On January 31, 1950, President Truman settled the issue with his momentous decision that the Commission should expedite work on the thermonuclear weapon.(6)

\section{Production Expansion}

David Lilienthal resigned on February 15th after three years as chairman of the Atomic Energy Commission. Although his dream of developing the full potential of the peaceful atom had not been fulfilled, the Commission under his leadership had become an effective government institution. Indeed, the future held great promise for the peaceful atom, but for the moment at least the military atom would continue to be in the ascendancy.

By mid July 1950 Gordon Dean had become chairman of the Commission, and the Nation was no longer in a twilight zone between peace and war. Following an attack by North Korean troops across the 38th parallel, President Truman ordered U.S. forces to the aid of South Korea. Suddenly increased military demands, added to the President's decision to develop the hydrogen bomb, threatened to exhaust the Commission's production capacity. Beginning in October 1950 the Commission embarked on a vast expansion program. During the next three years the construction of huge plants increased capacity at each step in the production chain. The new facilities included a feed materials production center at Fernald, Ohio; a plant to produce large quantities of lithium 6 at Oak Ridge; a gaseous-diffusion plant at Paducah, Kentucky; a whole new gaseous diffusion complex at Portsmouth, Ohio; two "Jumbo" reactors and a separation plant for producing plutonium at Hanford; and five heavy-water reactors at the Savannah River site in South Carolina for producing tritium from lithium 6 as well as plutonium. The three year three-billion-dollar expansion program represented one of the greatest federal construction projects in peacetime history.

In addition to having an impact on the Commission's expansion program, the Korean War also focused attention on the need for a continental test site. In December 1950, with the approval of the Department of Defense and the General Advisory Committee, the Commission selected the Las Vegas bombing and gunnery range as the site to conduct the January 1951 Ranger test series, the first atomic tests in the United States since the Trinity detonation at Alamogordo on July 16, 1945.(7)

The United States detonated the world's first thermonuclear device in the fall of 1952. Code-named Mike, the shot was part of the I $v y$ test series conducted at Enewetak By the end of 1953 more than thirty weapon test devices had been successfully fired at Pacific or Nevada sites, the result of extraordinary efforts by scientists and engineers at the Commission's Los Alamos weapon laboratory. A second weapon laboratory established at Livermore, California in early 1952, soon became the center of a weapon engineering and production network which included the Sandia Laboratory near Albuquerque, New Mexico, as well as new or expanded facilities in lowa, Texas, Missouri, Ohio, and Colorado.(8)

\section{Organizing the National Laboratories}

Fortunately the concentrated effort on weapon production did not mean a total neglect of the Commission's research laboratories. The Commission recognized the need to maintain the vitality of the national labs, and to encourage the university research teams and industry groups whose research on the peaceful uses of atomic energy would provide the technology of the future. The Metallurgical Laboratory at the University of Chicago had been reorganized by the Army in 1946 as the Argonne $\mathrm{Na}$ tional Laboratory. The following year the Commission obtained a new site for the lab at Argonne, Illinois and determined that the laboratory should become a large multidisciplinary research center for the midwest. Under the direction of Walter H. Zinn, one of Enrico Fermi's principal assistants in developing the world's first reactor, Argonne very quickly became the Commission's center for reactor development. (9)

The Clinton Laboratories, built during World War II at Oak Ridge, Tennessee, became the regional research center for southeastern United States. Reorganized in 1948 as the Oak Ridge National Laboratory, Oak Ridge became the Nation's largest supplier of radioisotopes for medical, industrial and physical research, as well as a regional center for research in chemistry, physics, metallurgy, and biology. The laboratory also conducted the largest radiation genetics program in the world.

To provide regional research facilities for the northeast, the Commission approved a plan by Associated Universities, Inc. to build and operate a laboratory at Upton, New York. The Brookhaven National Laboratory provided research facilities in reactor physics, high-energy accelerators, and the biomedical sciences. A fourth center in the far west was established by expanding the facilities of the University of California Radiation Laboratory at Berkeley. In addition to the regional centers the Commission continued to support the wartime research laboratories at a number of colleges and universities, and awarded and administered hundreds of contracts with research institutions, universities and nonprofit organizations for basic research in the physical and biological sciences.(10)

\section{Reactor Development}

Although by 1953 the vast production complex of the Atomic Energy Commission was almost totally dedicated to military purposes, the idea of a civilian nuclear power system based on American industry was very much alive. As early as 1947, Lilienthal had publicly encouraged a partnership with industry in developing the peaceful uses of atomic energy. The Commission had supported a modest but coherent plan for developing nuclear power and propulsion and had permitted a few industry committees 
behind the Commission's security barriers to evaluate the opportunities for commercial development. On December 20, 1951, at the Commission's Idaho Test station, Zinn and a group of engineers from the Argonne National Laboratory succeeded in producing a token amount of electricity from an experimental fast breeder reactor. This historic accomplishment demonstrated in a practical way that the atomic nucleus could serve mankind as a source of power.(11)

Probably the most successful reactor program in the 1950 's was the naval reactors project established and directed by Admiral Hyman G. Rickover. On June 14, 1952, at the keel-laying ceremony for the world's first nuclear powered ship, Chairman Gordon Dean noted that the propulsion of the submarine Nautilus would be the first practical utilization of atomic power, heretofore used primarily as an explosive. The Navy project later played a significant role in the widespread adoption of pressurized-water reactors by the nuclear power industry in the United States.(12)

By the end of 1952, technological developments had generated a broad interest in nuclear power in Congress as well as in industry, and the election of a Republican president brought further encouragement. Indeed, there was soon reason for optimism. Two outstanding accomplishments of the Eisenhower years, the 1953 Atomsfor-Peace plan, and the passage of the 1954 Atomic Energy Act were to have a significant impact on the Nation's nuclear program.(13)

\section{Atoms for Peace}

Speaking before the United Nation's General Assembly on December 8, 1953, President Dwight D. Eisenhower declared that "peaceful power from atomic energy is no dream of the future. . that capability, already proved, is here today."(14) The President's Atoms-for-Peace proposal became a major pronouncement of America's public policy concerning the international management of nuclear energy. With a sufficient supply of uranium to satisfy its own military needs, by 1954 the United States could turn its attention to the promotion of the peaceful uses of nuclear energy. (15)

Lewis Strauss had been President Eisenhower's special assistant for atomic energy prior to his appointment as Commission chairman in July 1953. Strongly committed to national security during his early years as a Commissioner, and supportive of Truman's decision to expedite the development of the thermonuclear weapon, Strauss was now in a position to work closely with Eisenhower in promoting the peaceful atom on a world-wide basis.

\section{The Atomic Energy Act of 1954}

The President's Atoms-for-Peace speech also focused attention on the need for a fundamental revision of the Atomic Energy Act of 1946 to enable the Commission to share technical and scientific information with foreign governments. On February 17, 1954, the President asked Congress to pass legislation "making it possible for American atomic energy development, public and private, to play a full and effective part in leading mankind into a new era of progress and peace." Exhaustive hearings in the spring of 1954 and Congressional debate during the early summer resulted in a new law which opened the door for an exchange of nuclear technology with other nations. Although industry did not gain the right to own fissionable material, liberal licensing provisions, greater access to technical data, and the right to own reactors provided the essential conditions for the private development of nuclear power in the United States.(16)

\section{The Five Year Plan}

Even before Congress had passed the Atomic Energy Act of 1954, the Commission had launched a new program for power reactor development. In early 1954 Strauss announced plans to test the basic designs then under study by building five experimental reactors within five years. Of the five reactor prototypes planned, the one with the most immediate impact on nuclear power development was the Pressurized Water Reactor (PWR) at Shippingport, Pennsylvania. Based on the technology developed for nuclear propulsion systems for submarines, Shippingport was completed on schedule in late 1957 as the Nation's first full-scale nuclear generating station.

The other reactor experiments constructed under the five year program included the Sodium Reactor Experiment built by North American Aviation, a Commission contractor in southern California; the Experimental Boiling Water Reactor constructed at the Commission's Argonne National Laboratory; and new models of the fast breeder and homogeneous reactor experiments built in the early 1950 's at the National Reactor Testing station in central Idaho, and the Oak Ridge National Laboratory in Tennessee. Of the five experiments in the program, the Shippingport and the Argonne boiling-water reactors encountered fewer technical problems, but each experiment contributed to the development of the technology needed to build full-scale nuclear power plants in the future.

\section{Cooperation with Industry}

The terms of the Atomic Energy Act enabled the Commission to encourage private industry to build its own nuclear plants, using fissionable material leased from the Government. Industry responded to the Commission's January 1955 Power Demonstration Reactor Program with four proposals covering all but one of the Commission's five prototypes. Thus by the end of 1957, the Commission had seven experimental reactors in operation and American industry was participating in nine independent or cooperative projects capable of producing almost 800,000 kilowatts of electricity by the mid-1960's. For the moment at least, prospects for the future of the peaceful atom were extremely encouraging.(17)

\section{International Participation}

In his Atoms-for-Peace proposal of December 8, 1953, President Eisenhower had proposed that the nuclear powers contribute portions of their stockpiles of normal uranium and fissionable materials to an international atomic energy agency, which would then allocate these materials toward peaceful uses. After three years of patient diplomatic negotiations, the International Atomic Energy Agency (IAEA) was formally inaugurated in Vienna, Austria on October 1, 1957. As head of the United States 
delegation to the first IAEA conference, Lewis Strauss delivered the President's message of hope that the fissioned atom would now be transformed from a symbol of fear to one of hope. The new spirit of international cooperation had been in evidence even earlier when more than 1400 scientists from 73 nations attended the first United Nations sponsored International Conference on the Peaceful Uses of Atomic Energy, held in Geneva, Switzerland in August 1965. Similar conferences were held in 1958, 1964 and 1971.

In addition to sponsoring the International Atomic Energy Agency, the United States gave strong support to Euratom, the European atomic energy community consisting of West Germany, France, Italy, Belgium, the Netherlands and Luxembourg. Formally inaugurated in January 1958, Euratom undertook to establish an integrated program for developing an atomic energy industry in Europe similar to the European Coal and Steel Community. Prior to the establishment of either the International Atomic Energy Agency or Euratom, the Atomic Energy Commission had negotiated a series of bilateral agreements to provide research reactors, power reactor fuel and technical information to friendly nations, as well as training programs for nuclear scientists and technicians. Although no bilateral agreements were made with the Soviet Union, Commission Chairman John A. McCone and his Soviet counterpart, Professor Vasily S. Emelyanov, signed a Memorandum on Cooperation on November 24, 1959, covering exchanges of visits and information on several unclassified areas of peaceful nuclear application. Similar memoranda in the 1960's and early 1970's covered joint experiments in the fields of high energy physics, controlled thermonuclear research and fast breeder reactors.(18)

\section{Weapon Testing and Fallout}

The detonation of the first shot in the Castle weapon test series in the spring of 1954, however, had threatened to cast a shadow over the glowing prospects for the peaceful atom, so recently kindled by Eisenhower's atomsfor-peace proposal. At the time of the Bravo shot on March 1, a Japanese fishing vessel had been within 82 nautical miles of the test area, close enough to receive a heavy dusting of radioactive fallout. By the time the ship, the Fukuryu Maru (or Lucky Dragon) returned to Japan the effects of the radiation exposure had become evident, and several members of the crew required hospitalization. The American and Japanese press accounts of the incident had made the public aware, probably for the first time, of the worldwide dangers of radiation from fallout. (19)

On February 15, 1955, with the approval of the President, Strauss released a major report on the "Effects of High-Yield Nuclear Explosions." The report did little to calm public apprehension, and mounting concerns found expression in numerous articles on radiation and fallout in scientific journals and other public media. Both the Committee on Armed Services and the Joint Committee on Atomic Energy held hearings in the spring of 1955 on problems associated with radioactive fallout. The following December the United Nations established a Scientific Committee on Radiation with the former director of the Commission's Division of Biology and Medicine, Shields Warren, as United States' representative. (20)
In January 1956 Commissioner Willard F. Libby revealed the existence of Project Sunshine, a study of global fallout from weapon testing which Libby had initiated in the fall of 1953 while serving on the General Advisory Committee. Commission laboratories and contractors had been analyzing data collected through a worldwide network monitoring the presence of strontium 90 in humans, foods and soils. Prior to 1953 public concern with radiation had focused primarily on workers in atomic energy projects. In 1957 the Joint Committee's hearings on the nature of radioactive fallout revealed for the first time the extent of the Commission's radiation research program. Millions of dollars were involved in more than 300 Commissionsponsored projects on various aspects of radiation and fallout.(21)

Testing of nuclear devices by the United States continued throughout the 1950's, although the Eisenhower Administration repeatedly expressed its willingness to suspend nuclear tests as part of a disarmament agreement. When the Conference of Experts convened in Geneva in the summer of 1958, the President announced that the United States was prepared to negotiate a test ban agreement and would voluntarily suspend all weapon testing after the completion of the Hardtack series in the fall. As a result an unpoliced moratorium period began on October 31, 1958, during which both the United States and the Soviet Union refrained from nuclear weapon experiments.(22)

\section{Limited Test Ban Treaty}

Three years later the Soviet Union abruptly ended the moratorium by announcing, on August 31, 1961, that they intended to resume testing. By now John F. Kennedy was in the White House, and Glenn Seaborg had succeeded John McCone as chairman. One of the original members of the General Advisory Committee and the first scientist appointed as chairman of the Commission, Seaborg served during the entire decade of the 1960's.

Although the Soviet Union tested a large number of high-yield weapons in the atmosphere during the autumn of 1961. President Kennedy limited the Commission's weapon laboratories to underground tests until April 25, 1962, when the first shot in the Dominic series was conducted at Christmas Island in the Pacific. With technical support from Seaborg and the Commission, the President at the same time had been earnestly pursuing a test ban agreement with the Soviet Union. It had been a long and arduous task bearing little fruit. In an address to the Nation on March 2, 1962, Kennedy had explained that he deplored the necessity of beginning atmospheric testing again, but "a nation which is refraining from tests obviously cannot match the gains of a nation conducting tests." (23)

Finally, after months of negotiations, a limited test ban treaty was signed in Moscow on August 5, 1963, prohibiting nuclear explosion tests in the atmosphere, outer space, or under water, but permitting underground detonations provided no radioactive debris crossed the borders of the country in which the test was being conducted.

In the absence of further success in negotiating a comprehensive test ban treaty, President Kennedy, and later Presidents Johnson and Nixon, continued to authorize 
underground tests in accordance with the 1963 treaty. Although the limitations of the treaty imposed severe technical problems, particularly in testing high-yield warheads, the Commission's laboratories nevertheless were highly successful in devising ways to improve and update nuclear weapons by testing underground.

\section{Civilian Power: The Proliferation of the Peaceful Atom in the Sixties}

The signing of the Limited Test Ban Treaty in August 1963 also had an impact on the civilian power program. The cessation of weapon testing in the atmosphere gave new hope that the peaceful atom might soon command as large a share of the Commission's time and budget as the military atom had for so many years.

Although the imminence of economic nuclear power had been a main theme at the 1958 Geneva Conference, recurring technical difficulties in many of the prototype and demonstration plants in several European countries continued in the next few years to frustrate hopes for a practical new source of electrical power. In the United States, however, prospects were somewhat more encouraging. In March 1962 President Kennedy had requested the Atomic Energy Commission to take a "new and hard look at the role of nuclear power" in the Nation's economy. In submitting the Commission's report several months later, Seaborg noted optimistically that the Commission's ten-year civilian power program, adopted in 1958, was on the threshold of attaining its primary objective of competitive nuclear power by 1968 . Suggested goals for the future included a concentration of resources in the most promising reactor svstems, the early establishment of a self-sufficient and growing nuclear power industry, and increased emphasis on the development of improved converter or breeder reactors which would conserve natural uranium resources. The report was broadly circulated and stimulated public confidence in the economic prospects for civilian nuclear power.(24)

On November 22, 1963, Lyndon B. Johnson became President of the United States. One of Johnson's first and probably most significant acts was to order a 25 percent cutback in production of enriched uranium and the shut down of four plutonium piles, with the expectation that other nations might be challenged to do the same. Although verification was difficult, Chairman Khruschev later announced production cutbacks in the Soviet Union.

Another milestone in civilian power development occurred on December 12, 1963, when the Jersey Central Power and Light Company announced that it had contracted for a large nuclear power reactor to be built at Oyster Creek near Toms River, New Jersey. According to the company's own evaluation, the plant would be competitive with a fossil fuel plant. For the first time an American utility company had selected a nuclear power plant on purely economic grounds without government assistance and in direct competition with a fossil-fuel plant. In a commencement address at Holy Cross College on June 10, 1964, President Johnson called it an "economic breakthrough." (25) Two months later private industry received further encouragement from Congress in the form of new legislation.

\section{Private Ownership Legislation}

On August 26, 1964, President Johnson brought to an end an eighteen-year mandatory government monopoly of special nuclear materials by signing into law the "Private Ownership of Special Nuclear Materials Act." Enriched uranium for power reactor fuel would no longer have to be leased from the government. Private entities would be permitted to assume title to special nuclear materials. Although the new law provided for a transition period for the changeover from government to private ownership, after June 20, 1973 private ownership of power reactor fuels would become mandatory. The Act also authorized the Commission to offer uranium enriching services to both domestic and foreign customers under long-term contracts, beginning on January 1, 1969. Most of the Atomic Energy Commision's literature on reactor technology had been declassified as early as 1955 . With the adoption of the Private Ownership Act in 1964, fissionable materials as well as reactors now entered the public domain, and a full-fledged nuclear industry became a possibility.(26)

But how would a full-fledged nuclear industry be regulated? Could one agency continue to regulate a single energy technology in a time of increasing energy needs? In a few years the energy crisis of 1973 would bring these questions into sharp focus.

\section{Nuclear Power Capacity}

The Commission's 1962 report on civilian power had projected 5,000 megawatts of nuclear power capacity by 1970 and 40,000 by 1980 . Within five years the outlook had changed so dramatically that in March 1967 the Commission issued a supplementary report doubling its previous predictions. Within a few years, however, even these revised statistics were exceeded. (By the end of 1974 two hundred and thirty-three nuclear central-station generating units, with a capacity of 232,000 megawatts, were either in operation, under construction, or on order in the United States.)(27)

\section{The Breeder Reactor}

In addition to predicting dramatic increases in megawatt capacity, the Commission's 1967 report on civilian nuclear power reaffirmed the promise of the breeder reactor for meeting long-term energy needs, and gave the Liquid Metal Fast Breeder Reactor (LMFBR) the highest priority for civilian reactor development. A major boost was given to the program four years later by President Richard Nixon. In his "clean energy" message to Congress on June 4, 1971, the President called for the commercial demonstration of a breeder reactor by 1980 , stating that "The breeder reactor could extend the life of our natural uranium fuel supply from decades to centuries, with far less impact on the environment than the power plants which are operating today."(28)

The fast breeder project included a demonstration plant in Oak Ridge, Tennessee - the Clinch River Breeder Reactor (CRBR)- and a test reactor in Richland, Washington - the Fast Flux Test Facility (FFTF). Clinch 
River promised to be a major step in the transition from technology to large-scale demonstration of the fast breeder concept. The project was launched in August 1972 with the signing of a memorandum of understanding between the Commission and the principal utility participants, the Commonwealth Edison Company and the Tennessee Valley Authority. The Commission would be responsible for research and development of the demonstration plant while the Commonwealth Edison Company and the Tennessee Valley Authority would engineer, manufacture and proof test equipment and systems.(29)

\section{Licensing and Regulation}

Under the terms of the Atomic Energy Act of 1954, Congress had given the Atomic Energy Commission the responsibility for regulating and licensing commercial atomic activities. As the Nation's electric power industry increasingly turned toward nuclear plants, the Commission found it necessary to modify its organizational structure to separate regulatory from non-regulatory functions. In 1961 the regulatory staff was separated from the General Manager's office and placed under a Director of Regulation who reported directly to the Commissioners. Two years later the regulatory and operational functions were separated physically when the regulatory staff was moved from the headquarters building in Germantown, Maryland to offices in Bethesda. (30)

Licensing procedures involved a series of technical reviews and public hearings, including an independent technical safety evaluation by the Advisory Committee on Reactor Safeguards. The Commission itself served as a final review board for all licenses granted, and maintained continuous surveillance of licensed reactors throughout their operating lifetime.

\section{Research}

The weapon requirements for national defense in the early years had forced the Commission to postpone goals for an all-out program of research on the peaceful atom. As seen in the development of the power reactor, however, there was a gradual shift in emphasis during the Eisenhower era, and the trend continued to gain momentum during the Kennedy and Johnson Years. In 1966 the AEC budget for the first time was divided about equally between weapons and peaceful uses.

Research and development programs in the 1960's and early 1970's produced a significant fund of knowledge about radiation and its effects, and provided basic data needed to determine radiation protection standards and to assess the environmental impact of nuclear technology. Advances in medical diagnostic techniques based on the use of radioisotopes and radiation machines added to the skills of the medical profession, while immunological research provided the knowledge needed for successful transplants. Other medical breakthroughs included the treatment of Parkinson's Disease, the preservation of cells for transfusion, and the introduction of small accelerators to produce short-lived radioisotopes for immediate use in patients. Although Oak Ridge produced virtually all of the radioisotopes available for physical and biomedical as well as for industrial applications, the Commission gradually transferred production, packaging, and shipping to commercial suppliers, while continuing to support research on new applications.(31)

During the 1960's the Commission produced a series of radioisotope-powered and reactor-powered electricalgenerating units for space applications. The first such unit was launched into space from Vandenburg Air Force Base in California on April 3, 1965, under the Systems for Nuclear Auxiliary Power (SNAP) program. Newly discovered heavy isotopes, such as Californium-252, were found useful in both research and industry. In addition, significant progress was made in developing cardiac pacemakers for human use and ultimately artificial hearts using radioisotopic-power sources. (32)

Major research facilities such as high energy accelerators were constructed and operated by the AEC. Building on the accomplishments of the Berkeley Bevatron and the Brookhaven Cosmotron in the 1950's, the Commission supported even larger accelerators in the 1960's and 1970 's, including the Alternating Gradient Synchrotron at Brookhaven, the Zero Gradient Synchrotron at Argonne, and the two-mile long Stanford Linear ACcelerator. The Fermi National Accelerator Laboratory, completed in 1972, contained the world's most powerful proton synchrotron. The principal centers for research on controlled thermonuclear (fusion) reactors were Oak Ridge, Los Alamos, Livermore, and Princeton, although many universities and industrial facilities were involved on a smaller scale.

\section{Applied Technology}

As nuclear technology developed, the Commission perfected special applications of nuclear power, such as nuclear explosives for earth moving and for extracting resources deep underground. Gnome, the first experiment in the Plowshare series, was conducted in December 1961 in a thick salt bed deposit near Carlsbad, New Mexico, while the first nuclear cratering experiment, Project Sedan, was completed the following July at the Nevada Test Site. Project Gasbuggy in 1967, Rulison in 1969, and Rio Blanco in 1973, tested methods for extracting natural gas from impermeable rock. In the early 1970's, the Commission directed applied technology projects toward environmental research, energy storage and transmission systems, synthetic fuels, and nonnuclear energy.

\section{Nonnuclear Research}

The scientific and technological expertise gained by the national laboratories in developing nuclear energy made the Commission a logical contender for a strong role in developing new energy options. The doors of the national labs first opened to nonnuclear research in 1960 when the Commission, in a special report to the Joint Committee on Atomic Energy, acknowledged "that the strong capabilities of the laboratories are not the exclusive resources of the atomic energy field; they are held in trust for the Nation as a whole." Accordingly, work from other federal agencies would be accommodated whenever the skills of the national laboratories were needed. (33)

On August 11, 1971, largely in response to President Nixon's energy message of June 4, Congress authorized the Atomic Energy Commission to undertake research and 
development projects geared to providing a variety of alternatives for meeting the Nation's energy needs. As a result the Commission's industrial contractors and national laboratories became involved in the areas of superconducting power transmission systems, energy storage, solar energy, geothermal resources, and coal gasification.(34)

\section{Reorganization}

James R. Schlesinger took over the helm of the Atomic Energy Commission in August 1971, as its twenty-fifth year as an agency was drawing to a close. American troops were still in Vietnam and anti-war protests were widespread. The Nation faced increasing demands for energy, a leveling out of domestic oil production, limitations on coal use due to environmental concerns, inadequate natural gas supplies, and field delays in the licensing and construction of nuclear power plants. The rapid growth in atomic energy activities in the previous decade and changing perspectives in nuclear technology clearly pointed to the need for a substantial reorganization of the Commission's operational and regulatory functions. For nearly a quarter of a century the Commission had focused research and development toward responding to national defense requirements, funding and developing new uses for atomic energy, and fostering the growth of a competitive and viable nuclear industry. The next few years would see increasing attacks on the Commission's role as a regulatory overseer of the nuclear industry, particularly in the areas of quality of product and public safety.(35)

As a first order of business, Schlesinger led the Commission in a comprehensive review of the agency's functions and organization. An economist and former assistant director of the Bureau of the Budget, Schlesinger announced the results of the review in December 1971. The first broad reorganizaton in ten years would bring together various related programs previously scattered throughout the agency. Developmental and operational functions formerly undiar the jurisdiction of the general manager would now be under six assistant general managers for Energy and Del slopment Programs, Research, Production and Management of Nuclear Materials, Environment and Safety Programs, National Security, and Administration. Reflecting expanding areas of Commission involvement were new divisions of Controlled Thermonuclear Research, International Security Affairs, and Applied Technology.(36) The second half of 1971 also saw a major revamping of the regulatory organization and functions.

\section{Calvert Cliffs Decision}

The Nixon Administration believed that nuclear power, as an environmentally "clean" fuel, could help the Nation produce the increasing supply of energy needed for the future. On the other hand ponderous licensing procedures and increasing environmental considerations lengthened the time necessary to bring nuclear power plants on line, and increased costs to the industry, and ultimately to the consumer. As Commissioner Doub informed the Atomic Industrial Forum in October 1971, the Commission harbored no illusions as to the magnitude of the task of trying to match "the capabilities of a dynamic and complex technology to the urgent energy and environmental needs of the country."(37)
The Federal Court of Appeals' August 4, 1971 landmark decision concerning the Calvert Cliffs nuclear power plant became a pivot point for a major revamping of the Commission's licensing procedures. The Court ruled that the Atomic Energy Commission's regulations for implementing the National Environmental Policy Act of 1969 in licensing procedures did not comply in several respects with the Act, and that the Commission should make an independent review and evaluation of all environmental effects at every decision point in the nuclear power plant licensing process.

Moving swiftly to implement the Court's ruling, the Commission made substantive changes in environmental review procedures. Both the Commission and the license applicant would now be required to consider the total impact of the proposed plant on the environment, including water quality. In addition, a cost-benefit analysis would balance the benefits of building the facility against a variety of alternatives. (38) These changes in procedures affected virtually all nuclear power plants whether licensed for operation or under review.

To expedite the additional procedures which the Calvert Cliff's decision required, Schlesinger made significant changes in the Commission's regulatory organization, and added additional personnel to the staff to help with the expanded reactor licensing workload. Additional changes in 1972 further streamlined the regulatory staff. Three directors consolidated the functions previously performed by seven divisions. All licensing activities were centered in the largest of the three, the Directorate of Licensing, headed by John F. O'Leary, former Director of the Bureau of Mines.(39)

\section{The Commission's Last Days}

Schlesinger left the Atomic Energy Commission in January 1973 to become head of the Central Intelligence Agency. He was succeeded as chairman by Dr. Dixy Lee Ray, a marine biologist from the state of Washington who had been appointed to the Commission by President Nixon in August 1972. The first woman to be chairman of the Atomic Energy Commission, Ray took over at a time when the Nation was faced with the monumental task of reconciling energy needs, environmental concerns and economic goals. More importantly for the Commission, criticism had begun to mount against an agency that regulated the very same energy source that it helped to produce and operate.

In June 1973, President Nixon directed the chairman of the Atomic Energy Commission to undertake an immediate review of federal and private energy research and development activities and to recommend an integrated program for the Nation.(40) The President's energy proposals to Congress the following January reflected the recommendations submitted by Chairman Ray in the December 1, 1973 report on "The Nation's Energy Future." Because of the energy crisis resulting from the October Arab oil embargo, the President had chosen to break tradition and present his energy request to Congress before delivering his State of the Union address. Both his proposal for a five-year $\$ 10$ billion energy research and 
development program, and his determination to double the total federal commitment to energy research and development for fiscal year 1975, were in line with the recommendations made by the Commission chairman. The Ray report also supported the President's recommendation to establish an Energy Research and Development Administration.(41)

\section{Reactor Safety}

In December 1973 the Commission announced new requirements for the performance of the emergency core cooling systems (ECCS) installed in light-water-cooled power reactors. Such systems provided the capability for emergency removal of heat from the reactor core in the event of a loss of the normal reactor coolant water. The Commission's action concluded a two-year public rulemaking hearing which had served as a focal point for public discussion of opposing viewpoints on the safety of nuclear power plants. Six months of hearing sessions, between January 27, 1972 and July 25, 1973, had produced a voluminous transcript, a clear witness to the complexity of the technical issues involved in nuclear safety. A constant advocate of the public's right to know and fully understand the possible dangers of radiation, the Joint Committee on Atomic Energy had also held a hearing in early 1973 on the safety of nuclear power plants.

Clearly the handwriting on the wall was spelling out the numbered days of the AEC in 1973. Although nuclear power constituted a significant part of the answer to the Nation's need for additional sources of energy, it was by no means the only answer as had been predicted in the early decades of the Commission's existence.

\section{Summary}

When President Ford signed the Energy Reorganization Act of 1974 on October 11, the Atomic Energy Commission's twenty-eight year stewardship of the Nation's nuclear energy program came to an end. On January 19, 1975, the Commission's research and development responsibilities were assumed by the Energy Research and Development Administration, and the regulatory and licensing functions by the Nuclear Regulatory Commission. Six thousand, three hundred and twenty Commission employees went to ERDA while one thousand nine hundred and seventy former regulatory personnel became part of the new Nuclear Regulatory Commission.

In the preceding twenty-eight years the Atomic Energy Commission had accomplished a large portion of the mission established by the Congress in 1946. First, through its weapon laboratories and production contractors, it had developed and stockpiled an array of sophisticated nuclear weapons which for nearly three decades had served as an important element in national defense. Also in the area of defense, the Commission had supported the development of nuclear propulsion reactors which made possible the creation of a fleet of reliable nuclear submarines and surface ships.

Although for many years military related programs commanded the major portion of the budget, the Commission had initiated and supported extensive research in the nuclear sciences. The research contract and the national laboratory had become key instruments in the widespread development and application of nuclear technology for scientific, medical, and industrial purposes. Through participation in the International Atomic Energy Agency, international conferences and bilateral agreements, the United States shared the new technology with other nations.

The congressional mandate of 1946 also called for the use of atomic energy in a way that would strengthen free competition in private enterprise. Although the severe restrictions of the 1946 Act made atomic energy virtually a government monopoly, the Commission in less than a decade advanced nuclear technology to the point where industrial participation was feasible, and then encouraged the passage of new legislation in 1954 which made a nuclear industry possible. By the early 1970's nuclear power offered a promising option for meeting national and world energy needs.

In carrying out the Congressional mandate of 1946, the Atomic Energy Commission essentially worked its way out of existence. After concentrating on defense commitments in the early years, the Commission then focused on the development of a viable nuclear industry, only to come under fire in the late 1960's and 1970's for being in the position of regulating the same industry it helped to create.

This difficulty had been foreseen in 1961 when the functions of the agency were divided between the General Manager and the Director of Regulation. Then in 1963 the two functions were physically separated by being housed in different geographical locations. Finally, the legal separation of the developmental and regulatory functions, requested in 1973 by the Commission itself, was accomplished by the Energy Reorganization Act of 1974. The regulatory and licensing responsibilities became the exclusive focus of a new agency headed by a five-member board, the Nuclear Regulatory Commission, while the developmental functions were placed under a single administrator in a second agency, the Energy Research and Development Administration.

In the preceding decade the Atomic Energy Commission had lost much of its privileged status with Congress and the American public. The exclusive monopoly and the mantle of secrecy had been largely removed, and no longer did atomic energy seemingly provide the perfect formula for both military defense and civilian energy needs. Regulatory restrictions and environmental concerns were a large part of the reason for the demise of the AEC, but more important was the recognition that a single technology should not be the exclusive focus of one agency. The energy crisis would now require the coordination of all major energy programs in a new research and development agency, whose primary purpose would be to assist the Nation in achieving energy independence.

As a legacy to the new agency, the Atomic Energy Commission passed on its unique production facilities, its valuable network of national laboratories, and the proven technological skills, resourcefulness, and experience of its personnel. Three years later the Energy Research and Development Administration, like the Atomic Energy Commission before it, became part of an even larger organization. On October 1, 1977 Congress created a cabinet-level Department of Energy to coordinate Federal energy policies and programs. 


\section{FOOTNOTES}

1. Sect. 1(a), Atomic Energy Act of 1946 (Public Law 585) 78th Cong. 1st sess.

2. Corbin Allardice and Edward R. Trapnell, The Atomic Energy Commission (New York: Praeger Publishers, 1974), pp. 31-32 (hereafter cited as Allardice and Trapnell, The AEC).

3. Dr. Richard G. Hewlett, former Chief Historian of the $A E C$, believes that the most influential group in the early years was not the Commission itself but its General Advisory Committee consisting of such famous scientists as J. Robert Oppenheimer, James B. Conant, Enrico Fermi and Isador I. Rabi. Richard G. Hewlett," "The Advent of Nuclear Power, 1945. 1968" (Paper delivered before the American Association for The Advancement of Science, Dallas, TX, Dec. 28, 1968), p. 4 (hereafter cited as Hewlett, "The Advent of Nuclear Power").

4. Richard G. Hewlett, "Nuclear Power in the Public Interest: The Atomic Energy Act of 1954" (Paper delivered before the American Historical Association, Dallas, TX, Dec. 1977), pp. 1-3.

5. Richard G. Hewlett, "The AEC in Retrospect" (unpublished ms., Historian's Office, Feb. 10, 1976), p. 12 (hereafter cited as Hewlett, "The AEC in Retrospect").

6. Public Papers of the Presidents of the United States: Harry S. Truman 1950 (Washington: Government Printing Office, 1965), p. 138. For a detailed presentation of the decision on the hydrogen bomb, see Richard G. Hewlett and Francis Duncan, Atomic Shield, 1947-1952, Vol. II of A History of the United States Atomic Energy Commission (University Park: Pennsylvania State University Press, 1969), pp. 362 409 (hereafter cited as Hewlett and Duncan, Atomic Shield).

7. Hewlett and Duncan, Atomic Shield, pp. 534-35, 56364.

8. Hewlett and Duncan Atomic Shield, pp. 411, 424-30, 441; "The Eisenhower Imprint," unpublished ms., Department of Energy Historian's Office, pp. 3-4; "A History of the Expansion of AEC Production Facilities," Report by the General Manager, Aug. 16, 1963, pp. 13-20.

9. Hewlett and Duncan, Atomic Shield, p. 432; Richard G. Hewlett and Francis Duncan, Nuclear Navy 19461962 (Chicago: University of Chicago Press, 1974), pp. 54.55 (hereafter cited as Hewlett and Duncan, Nuclear Navy).

10. Atomic Shield, pp. 222-227, 432.

11. Proposal for Industrial Development of Atomic Energy, enc. C.A. Thomas to S. Pike, June 20, 1950; David Lilienthal, Speech before the Economic Club, Detroit, MI, Oct. 6, 1947; AEC Press Release 59, Oct. 6, 1947; Hewlett and Duncan, Atomic Shield, pp. 495-98.
12. Hewlett and Duncan, Nuclear Navy, pp. 178-79, 23557; Dean Diary, June 14, 1952.

13. Hewlett, "The Advent of Nuclear Power", p. 12.

14. Public Papers of the Presidents of the United States, 1953, Dwight D. Eisenhower (Washington: Government Printing Office, 1960), pp. 813-22.

15. For a discussion of Atoms for Peace as an instrument of foreign policy, see Jack M. Holl, "Eisenhower's Peaceful Atomic Diplomacy: Atoms for Peace in the Public Interest" (Paper delivered before the American Historical Association, Dallas, TX, Dec. 2330, 1977), p. 1 (hereafter cited as Holl, "Eisenhower's Peaceful Diplomacy").

16. "Message from the President of the United States, "House Document, 83 Cong., 2 sess., no. 328 (Feb. 17, 1954); Richard G. Hewlett, "Industry and the Atomic Energy Commission, 1947-1954" (Paper delivered at a joint session of the Society for the History of Technology and the Organization of American Historians, Chicago, IL, April 27, 1967), pp. 21-22.

17. Joint Committee on Atomic Energy, Current Statement of the Atomic Energy Commission on the FiveYear Reactor Development Program, May 4, 1955 (Washington: Government Printing Office, 1955).

18. Holl, "Eisenhower's Peaceful Diplomacy" pp. 9-18; AEC, Twenty-third Semiannual Report, January 1958 (Washington: Government Printing Office, 1958), pp. 189-221.

19. Robert A. Divine, Blowing on the Wind, the Nuclear Test Ban Debate 1954-1960 (New York: Oxford University Press, 1978), pp. 3-18; AEC, Sixteenth Semiannual Report, July 1954 (Washington: Government Printing Office, 1958), pp. 51-5; Richard G. Hewlett and Jack M. Holl, "Nuclear Weapons: A New Reality" (unpublished ms., Historian's Office, 1981), pp. 61-63.

20. "A Report by United States Atomic Energy Commission on Effect of High-Yield Nuclear Explosions," Appendix 7, Eighteenth Semiannual Report of the Atomic Energy Commission July 1955 (Washington: Government Printing Office, 1955), pp. 147.54; Senate Committee on Armed Services, Civil Defense Program, 84th Cong., 1st Sess., Feb. 22, 1955, p. 2; Joint Committee on Atomic Energy, Health and Safety Problems Associated with Atomic Explosions, April 15, 1955; AEC, Major Activities in The Atomic Energy Programs, January-June 1956, p. 16.

21. Willard F. Libby, "Radioactive Fallout and Radioactive Strontium," Northwestern University, Evanston, IL, Jan. 19, 1956; Joint Committee on Atomic Energy Press Release No. 80, April 18, 1957.

22. AEC, Twenty-fifth Semi-Annual Report of the Atomic Energy Commission, January 1959 (Washington: Government Printing Office, 1960), pp. 
179-80. Richard G. Hewlett, “Nuclear Weapon Testing and Studies Related to Health Effects: An Historical Summary" (unpublished ms., Oct. 1980), pp. 43-44.

23. Major Activities in the Atomic Energy Program, January-December 1961 (Washington: Government Printing Office, 1962), pp. 161-62; AEC, Major ACtivities in the Atomic Energy Programs, JanuaryDecember 1962 (Washington: Government Printing Office, 1963), p. 234; Public Papers of Presidents of the United States: John F. Kennedy 1962 (Washington: Government Printing Office, 1963), pp. 186-92.

24. AEC, Civilian Nuclear Power-A Report to the President-1962, Nov. 20, 1962.

25. "Annual Message to the Congress on the State of the Union," Jan. 8, 1964; "Commencement Address at Holy Cross College," June 10, 1964, both in Public Papers of the Presidents: Lyndon B. Johnson, (Washington: Government Printing office, 1965), pp. 117, 763-764.

26. AEC, Annual Report to Congress for 1964, (Washington: Government Printing Office, 1965), pp. 12-14; Hewlett, "The AEC in Retrospect," p. 18; "Remarks Upon Signing Bill Permitting Private Ownership of Nuclear Materials," Public Papers of the Presidents: Lyndon B. Johnson, (Washington: Government Printing Office, 1965), p. 1006.

27. AEC, Civilian Nuclear Power, The 1967 Supplement to the 1962 Report to the President, February, 1967; AEC, 1974 Annual Report to Congress, p. 239.

28. Richard M. Nixon, "A Program to Insure an Adequate Supply of Clean Energy in the Future," June 4, 1971, as reprinted in Executive Energy Documents, published by the Senate Committee on Energy and Natural Resources, July 1978, pp. 1-12 (Hereafter cited as Executive Energy Documents).

29. "Operating and Developmental Functions," AEC 1972 Annual Report to Congress, pp. 10-12; "AEC Continues Developmental Push for Breeder Reactor," AEC Announcement 0-10, January 29, 1971.

30. AEC, Major Activities in the Atomic Energy Programs, January-December 1961 (Washington: Government Printing Office 1962), pp. 337-38; Richard G. Hewlett, "The Development of the Nuclear Power Industry" (unpublished ms., Historian's Office, 1974), pp. 13-14; AEC, Major Activities in the Atomic Energy Programs, JanuaryDecember 1961, p. 337-38.
31. AEC, 1974 Annual Report to Congress, (Washington: Government Printing Office, 1974), pp. 24-26.

32. AEC Annual Report to Congress for 1965, (Washington: Government Printing Office, 1966), p. 151; Annual Report to Congress for 1966, (Washington: Government Printing Office, 1967), p. 211; AEC, 1974 Annual Report to Congress, p. 114.

33. "Atomic Energy Research in the Life and Physical Sciences-1960," A Special Report of the United States Atomic Energy Commission, January 1961, (Washington: Government Printing Office, 1961); AEC, Annual Report to Congress for 1960, (Washington: Government Printing Office, 1961), p. 156-57.

34. Authorization Act for Fiscal Year 1972 (PL. 92-84, Sections 31-33, Aug. 11, 1971; Richard G. Hewlett, "Nonnuclear Energy Research in the Atomic Energy Commission" (unpublished ms., Historian's Office, 1974).

35. Corbin Allardice and Edward R. Trapnell, The Atomic Energy Commission (New York: Praegar Publishers, 1974), pp. 131-32.

36. "Reorganization of Atomic Energy Operating Functions," AEC Announcement 216, Dec. 7, 1971.

37. "The Right to be Heard-Laying It on the Line," Remarks given by AEC Commissioner William $O$. Doub (at 1971 Annual Conference of the Industrial Forum, Oct. 18, 1971); President Richard M. Nixon, Message to the Congress on "A Program to Insure an Adequate Supply of Clean Energy in the Future," June 4, 1971 in Executive Energy Documents, p. 1.

38. "Statement by the AEC on Court of Appeals Decision in Calvert Cliffs Litigation," AEC Announcement 0-134, Aug. 4, 1971; AEC Annual Report to Congress for 1971 (Washington: Government Printing Office, 1972) pp. 1-2, 21-23.

39. "AEC Makes Organizational Changes to Strengthen Its Regulatory Program," Press Release 0-207, Nov. 11, 1971.

40. Richard M. Nixon, "Statement," June 29, 1973 in Executive Energy Documents, pp. 49-55; Statement by Dixy Lee Ray, Chairman of the AEC, AEC Press Release R-274, June 29, 1973.

41. The Nation's Energy Future, A Report to President Richard M. Nixon, December 1973 (Washington: Government Printing Office, 1973) p. ix; "Proposals to Deal with the Energy Crisis," Jan. 23, 1974, in Executive Energy Documents, pp. 119-134; White House Fact Sheet, "Energy Research and Development," Oct. 11, 1973. 


\section{APPENDIX I \\ (Personnel)}

\section{Joint Committee on Atomic Energy}

CHAIRMEN
Brien McMahon
Burke B. Hickenlooper
Brien McMahon
Carl T. Durham (Acting)
W. Sterling Cole
Clinton P. Anderson
Carl T. Durham
Clinton P. Anderson
Chet Holifield
John O. Pastore
Chet Holifield
John O. Pastore
Chet Holifield
John O. Pastore
Melvin Price

DATES OF SERVICE

1946 -

$1947 \cdot 1948$

$1949-1952$ (d. $7 / 28 / 52$ )

1952 .

$1953 \cdot 1954$

$1954 \cdot 1956$

$1956 \cdot 1958$

1959 -

$1960-1961$

$1962 \cdot 1964$

$1965 \cdot 1966$

$1967-1968$

$1969-1970$

$1970-1972$

1973 -

\section{Military Liaison Committee}

\section{CHAIRMEN}

Lt. Gen. Lewis H. Brereton, USAF

Donald F. Carpenter

William Webster

Robert F. LeBaron

Herbert B. Loper

Gerald W. Johnson

W.J. Howard

Carl Walske

Chet Holifield

Carl Walske

Donald R. Cotter
DATES OF SERVICE

1946 - 1948

1948 -

$1948-1949$

$1949 \cdot 1954$

$1954-1960$

1961 - 1962

$1963-1965$

1966 - 1969

1970 -

1971 - 1972

1973 -

\section{General Advisory Committee}

\section{CHAIRMEN}

J. Robert Oppenheimer Isidor I. Rabi

Warren C. Johnson

Kenneth S. Pitzer

Manson Benedict

L.R. Hafstad

Norman F. Ramsey

Howard G. Vesper

Lombard Squires
DATES OF SERVICE

1946 - 1952

$1952-1956$

1956- 1959

$1960-1961$

1962 - 1963

1964 - 1967

1968 -

$1969-1972$

1973 - 
Sumner T. Pike

David E. Lilienthal, Chairman

Robert F. Bacher

William W. Waymack

Lewis L. Strauss

Gordon Dean

Chairman

Chairman

Henry DeWolf Smyth

Thomas E. Murray

Thomas Keith Glennan

Eugene M. Zuckert

Joseph Campbell

Willard F. Libby

John Von Neumann

Harold S. Vance

John S. Graham

John Forrest Floberg

John A. McCone, Chairman

John H. Williams

Robert E. Wilson

Loren K. Olson

Glenn T. Seaborg, Chairman

Leland J. Haworth

John G. Palfrey

James T. Ramey

Gerald F. Tape

Mary I. Bunting

Wilfred E. Johnson

Samuel M. Nabrit

Francesco Costagliola

Theos J. Thompson

Clarence E. Larson

James R. Schlesinger, Chairman

William O. Doub

Dixy Lee Ray

Chairman

William E. Kriegsman

William A. Anders
Oct. 31,1946

Nov. 1, 1946

Nov. 1, 1946

Nov. 5, 1946

Nov. 12, 1946

July 2, 1953

May 24, 1949

July 11, 1950

May 30, 1949

May 9, 1950

Oct. 2, 1950

Feb. 25, 1952

July 27, 1953

Oct. 5, 1954

Mar. 15, 1955

Oct. 31, 1955

Sept. 12, 1957

Oct. 1, 1957

July 14, 1958

Aug. 13, 1959

Mar. 22, 1960

June 23, 1960

Mar. 1, 1961

Apr. 17, 1961

Aug. 31, 1962

Aug. 31, 1962

July 15, 1963

June 29, 1964

Aug. 1, 1966

Aug. 1, 1966

Oct. 1, 1968

June 12, 1969

Sept. 2, 1969

Aug. 17, 1971

Aug. 17, 1971

Aug. 8, 1972

Feb. 6, 1973

June 12, 1973

Aug. 6, 1973
Dec. 15, 1951

Feb. 15, 1950

May 10, 1949

Dec. 21, 1948

Apr. 15, 1950

June 30, 1958

June 30, 1953

June 30, 1953

Sept. 30, 1954

June 30, 1957

Nov. 1, 1952

June 30, 1954

Nov. 30, 1954

June 30, 1959

Feb. 8, 1957

Aug. 31, 1959

June 30, 1962

June 23, 1960

Jan. 20, 1961

June 30, 1960

Jan. 31, 1964

June 30, 1962

Aug. 16, 1971

June 30, 1963

June 30, 1966

June 30, 1973

Apr. 30, 1969

June 30, 1965

June 30, 1972

Aug. 1, 1967

June 30, 1969

Nov. 25, 1970

June 30, 1974

Jan. 26, 1973

Aug. 17, 1974

Jan. 18, 1975

Jan. 18, 1975

Jan. 18, 1975

\section{General Managers}

Carroll L. Wilson

Marion Boyer

Kenneth D. Nichols

Kenneth F. Fields

Paul F. Foster

A. R. Luedecke

R. E. Hollingsworth

John A. Erlewine
Dec. 31, 1946

Nov. 1, 1950

Nov. 1, 1953

May 1, 1955

July 1, 1958

Dec. 1, 1958

Aug. 11, 1964

Feb. 15, 1974
Aug. 15, 1950

Oct. 31, 1953

Apr. 30, 1955

June 30, 1958

Nov. 30, 1958

July 31, 1964

Dec. 31, 1973

Dec. 31,1974 


\section{APPENDIX II \\ Chronology}

\section{DATE}

August 1, 1946

January 1, 1947

September 1947

March 1, 1948

April-May 1948

March 1, 1949

August 29, 1949

January 31, 1950

June 27, 1950

December 20, 1951

June 14, 1952

November 1952

December 8, 1953

March 1, 1954

August 30, 1954

January 10, 1955

August 8-20, 1955

October 1, 1957

December 23, 1957

August 22, 1958

November 24, 1959

March 1961

August 31, 1961

December 10, 1961

April 25, 1962

August 5, 1963

August 26, 1964

October 1964

\section{EVENTS}

Atomic Energy Act of 1946 signed by President Truman.

Atomic energy program transferred from the Manhattan Engineer District to the Atomic Energy Commission.

Start of construction on first of two new Hanford reactors.

Oak Ridge National Laboratory officially established to continue work of Clinton Laboratories established in 1943.

Operation Sandstone, the first AEC nuclear test series conducted at Enewetak Atoll.

Announcement by AEC of selection of a site for the National Reactor Testing Station in Idaho.

Soviet Union detonated nuclear device.

President Truman directs Commission "to continue work on all forms of weapons, including the so-called hydrogen or super-bomb."

Truman orders U.S. forces to aid of South Korea.

Experimental Breeder Reactor No. 1 (EBR-1) first reactor to produce electric power from nuclear energy.

Keel of the world's first nuclear-powered ship, the submarine Nautilus, laid at Groton, Connecticut.

World's first thermonuclear device detonated by U.S. at Enewetak.

Announcement by President Eisenhower of the Atoms-for-Peace program and proposal to establish an international agency to promote peaceful applications of atomic energy.

First shot in Castle weapon test series fired in Pacific.

President Eisenhower signed the Atomic Energy Act of 1954, a major revision of the 1946 Act. The new law made possible greater participation by private industry and more cooperation with other countries in developing the peaceful uses of nuclear energy.

Announcement by the AEC of the Power Demonstration Reactor Program, under which the $A E C$ and industry would cooperate in the construction and operation of experimental power reactors.

First United Nations International Conference on the Peaceful Uses of Atomic Energy, in Geneva, Switzerland.

International Atomic Energy Agency inaugurated in Vienna, Austria. AEC Chairman Lewis Strauss announced U.S. offer to make 5,000 kilograms of uranium 235 available to the agency.

Full-power operation of the Shippingport Atomic Power Station, the world's first full-scale nuclear power plant, at Shippingport, Pennsylvania.

President Eisenhower announced moratorium on weapon testing to begin on October 31 .

AEC Chairman John A. McCone and Professor Vasily S. Emelyanov signed Memorandum of Cooperation between, U.S. and U.S.S. R.

Regulatory functions separated from General Manager's Office and placed under a Director of Regulation.

Soviet Union broke moratorium and began testing nuclear weapons.

Project Gnome, the first Plowshare nuclear detonation, conducted in New Mexico.

First shot in Dominic series conducted at Christmas Island in the Pacific.

Limited test ban treaty between U.S., U.K., and U.S.S.R. signed in Moscow.

President Johnson signed Private Ownership of Special Nuclear Materials Act.

The nuclear-powered surface ships, Enterprise, Long Beach and Bainbridge, completed "Operation Sea Orbit," a round-the-world cruise without logistic support of any kind. 
AEC issued a permit to Jersey Central Power and Light Company for the construction of a nuclear power plant at Oyster Creek, New Jersey. This was the first civilian power reactor to be built on a competitive basis with conventional plants and without government assistance.

April 3, 1965

The first launching and operation of a nuclear reactor in space (SNAP-10A).

March 5, 1970

Ratification of the Treaty for the Nonproliferation of Nuclear Weapons by the United States, the United Kingdom, and the Soviet Union and 45 other nations.

June 4, 1971

President Nixon announced as a national goal a commitment to complete LMFBR demonstration plant by 1980 .

July 23, 1971

Calvert Cliffs decision regarding AEC licensing procedures for nuclear power plants.

March 1972

Completion of National Accelerator Laboratory at Batavia, Illinois, world's most powerful proton synchrotron.

October 17, 1973 Organization of Arab Petroleum Exporting Countries embargoed oil to the United States.

December 1, 1973

AEC Chairman Dixy Lee Ray submitted report to President Nixon on "The Nation's Energy Future."

October 11, 1974

Energy Reorganization Act of 1974 signed by President Ford.

August 4, 1977

Department of Energy Reorganization Act signed by President Carter. 


\section{APPENDIX III \\ Laboratories and Production Facilities}

\section{Atomic Energy Commission}

\begin{abstract}
AEC facility
Multiprogram Laboratories

Argonne National Laboratory

Brookhaven National Laboratory ............

Lawrence Berkeley Laboratory... . . . . . . . . . . . .

Lawrence Livermore Laboratory.............

Los Alamos Scientific Laboratory. . . . . . . . . . .

Oak Ridge National Laboratory. . . . . . . . . . .

Pacific Northwest Laboratory ..............
\end{abstract}

\section{Engineering Development}

Bettis Atomic Power Laboratory. . . . . . . . . . . . .

Hanford Engineering Development Lab. .........

Knolls Atomic Power Laboratory . . . . . . . . . . . .

Liquid Metal Engineering Center..............

Idaho National Engineering Lab. . . . . . . . . . . .

Naval Reactors Facility, INEL ...............

Sandia Laboratories.

Savannah River Laboratory................

Shippingport Atomic Power Station ...........

\section{Specialized Physical Research Laboratories}

Ames Laboratory .................... Fermi National Accelerator Laboratory .......... Notre Dame Radiation Lab. . . . . . . . . . . . . . . . . Princeton Plasma Physics Lab. . . . . . . . . . . . . . . Stanford Linear Accelerator Center

Specialized Biomedical Research Laboratories

Comparative Animal Research

Laboratory........................

Franklin McLean Memorial Research Inst,

(formerly Argonne Cancer Res. Hosp.). ........

Inhalation Toxicology Res. Inst. ..............

Laboratory of Nuclear Medicine \&

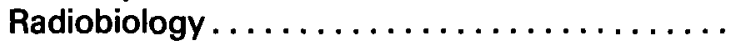

Laboratory of Radiobiology...............

MSU/AEC Plant Research Lab. . . . . . . . . . . . .

ORAU Research Facilities ..................

Puerto Rico Nuclear Center................

Radiobiology Laboratory ..................

Radiobiology Laboratory ..................

Savannah River Ecology Lab. ................

U. of Rochester Med. Lab.
Location

Chicago, III. ........

Upton, N.Y.........

Berkeley, Ca. ........

Livermore, Ca.......

Los Alamos, N. Mex..

Oak Ridge, Tenn.....

Richland, Wash. ....

Pittsburgh, Pa...... Richland, Wash. .... Schenectady, N.Y. . . Santa Susana, Ca....

Idaho Falls, Id. ...... . Idaho Falls, Id. ...... . Albuquerque, N. Mex. \& Livermore, Ca. . .

Aiken, S.C......... Shippingport, Pa. ...

Ames, lowa ........ Batavia, III. ......... South Bend, Ind..... Princeton, N.J.. . . . . . Palo Alto, Ca........

Oak Ridge, Tenn.....

Chicago, III . . . . . . . . Albuquerque, N. Mex.

Los Angeles, Ca. .... San Francisco, Ca. .. E. Lansing, Mich..... Oak Ridge, Tenn... . .

Mayaguez and Rio Piedras, P.R....... Davis, Calif. ........ Salt Lake City, Utah . Aiken, S.C.......... Rochester, N.Y......
Contractor-operator

Univ. of Chicago and Argonne Universities Assn. Associated Universities, Inc. University of California University of California University of California Nuclear Div., Union Carbide Corp.

Pacific Northwest Div. Battelle Memorial Inst.

Westinghouse Electric Corp. Westinghouse Hanford Co. General Electric Co.

Atomics International Div. Rockwell Int'I Corp.

Aerojet Nuclear Co. Westinghouse Electric Corp. Sandia Corp. (Western Electric-Bell System) E.I. du Pont de Nemours \& Co Duquesne Light Co.

lowa State U. of Sci. \& Tech. Universities Research Assn.

Univ. of Notre Dame

Princeton University

Stanford University

\section{University of Tennessee \\ University of Chicago \\ Lovelace Foundation of Medical Education and Research}

Univ. of Calif. at L.A. (UCLA)

Univ. of Calif. Medical Center

Michigan State University

Oak Ridge Associated

Universities

University of Puerto Rico

University of Calif. (Davis)

University of Utah

University of Georgia

University of Rochester 
Production, Development, and Fabrication Centers

Burlington-AEC Plant

Feed Materials Plant

Feed Materials Plant . . . . . . . . . . . . . . . .

Feed Materials Plant.

Hanford Works

Idaho Chemical Processing Plant . .

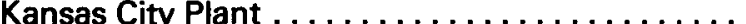

Mound Laboratory . . . . . . . . . . . . . . . . . . .

Nevada Test Site.

Oak Ridge Gaseous Diffusion Plant

Paducah Gaseous Diffusion Plant. .

Portsmouth Gaseous Diffusion Plant

Pantex Plant

Pinellas Plant.

Rocky Flats Plant

Savannah River Plant

Y-12 Plant
Ashtabula, Ohio....

Oak Ridge, Tenn....

Burlington, lowa ....

Fernald, Ohio .......

Paducah, Ky. ........

Richland, Wash.

INEL, Idaho

Kansas City, Mo.....

Miamisburg Ohio...

Mercury, Nev. ......

Paducah, Ky. .......

Portmouth, Ohio ....

Amarillo, Texas .....

Clearwater, Fla. .....

Golden, Colo........

Aiken, S.C.........

Oak Ridge, Tenn.....
Mason \& Hanger-Silas Mason Co., Inc.

Reactive Metals, Inc.

National Lead Co.

Nuclear Div., Union Carbide Corp.

Atlantic-Richfield Hanford Co. and United Nuclear, Inc.

Allied Chemical Corp.

Bendix Corp.

Monsanto Research Corp.

Reynolds Electrical \& Engineering Co.; EG\&G, Inc.; and Holmes \& Narver Inc. Nuclear Div., Union Carbide Corp.

Nuclear Div., Union Carbide Corp.

Goodyear Atomic Corp.

Mason \& Hanger-Silas Mason Co. Inc.

General Electric Co.

Atomics International Div. Rockwell International Corp. E.l. du Pont de Nemours \& Co. Nuclear Div., Union Carbide Corp. 


\title{
APPENDIX IV
}

\author{
Organization Charts
}




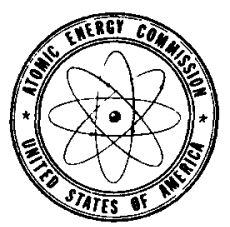

U.S. ATOMIC ENERGY COMMISSION

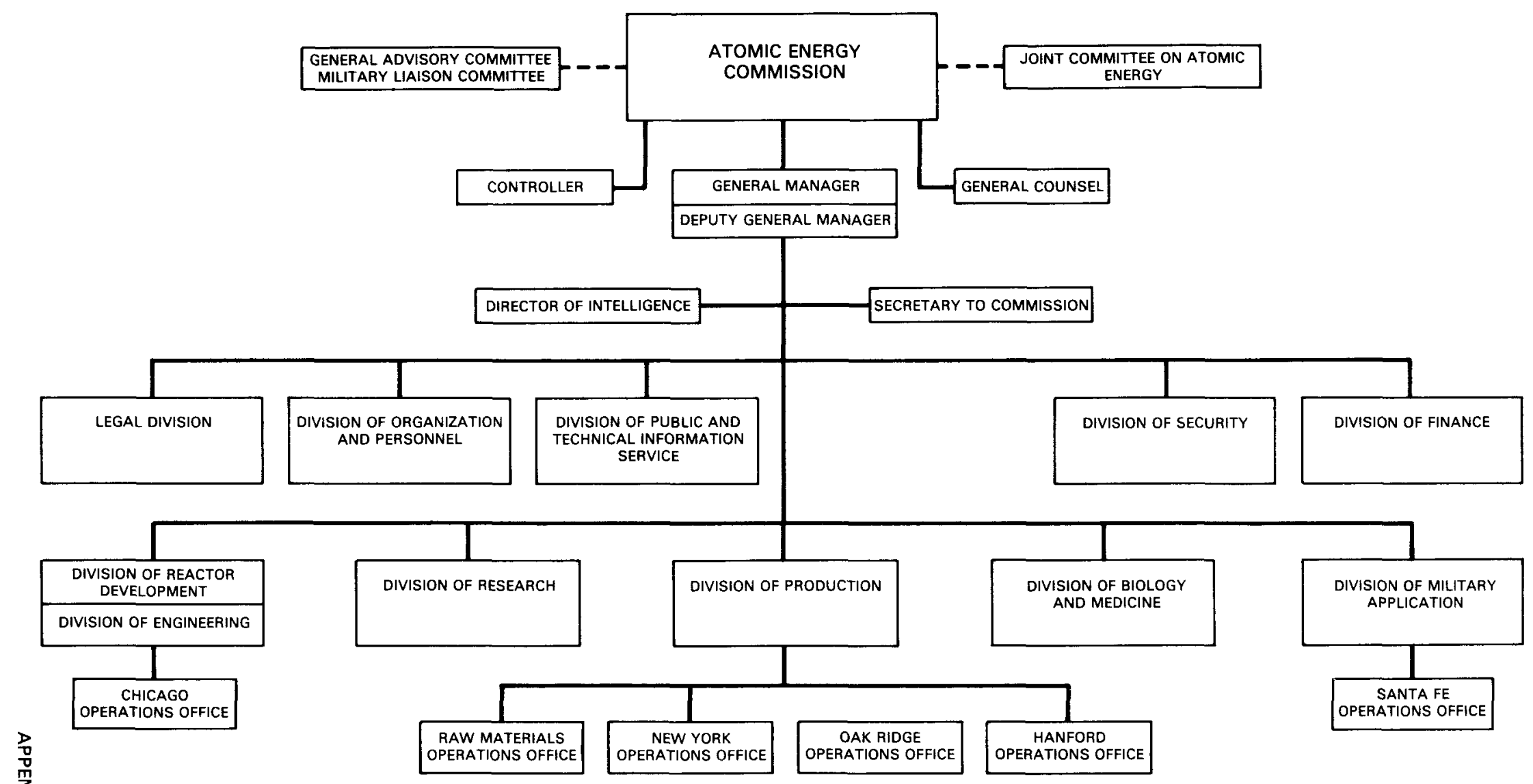




\section{UNITED STATES \\ ATOMIC ENERGY COMMISSION}

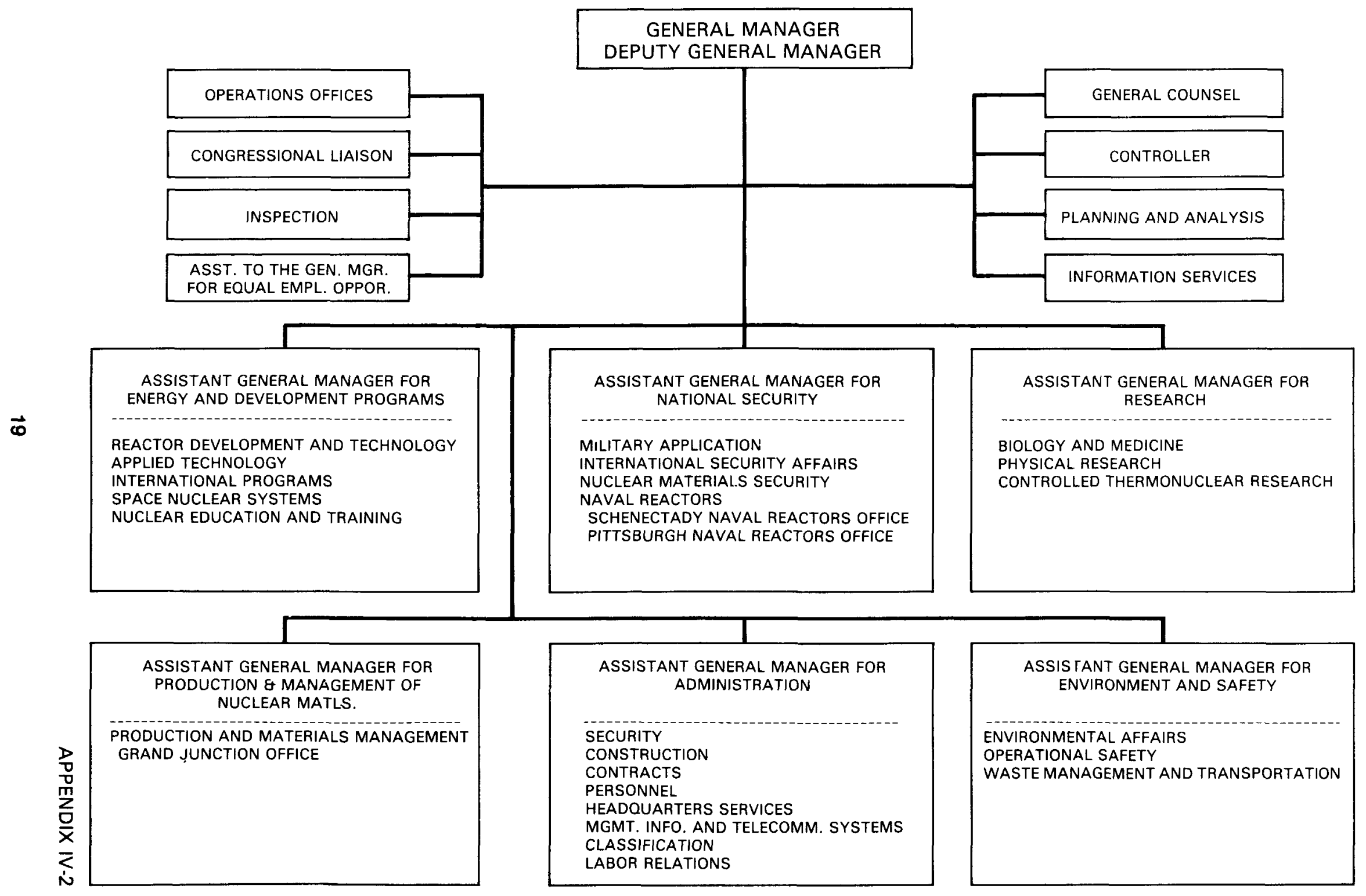




\section{ATOMIC ENERGY COMMISSION}

REGULATORY ORGANIZATION

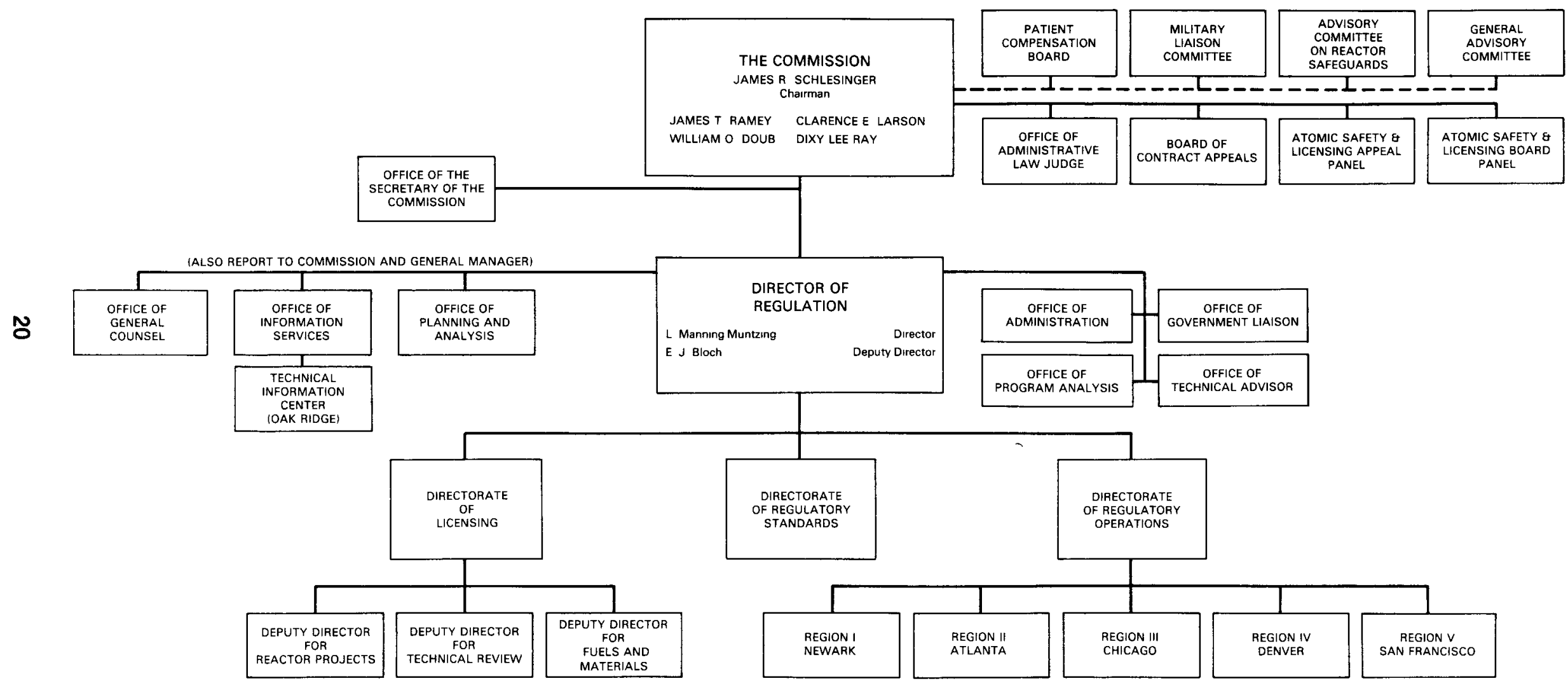


UNITED STATES

ATOMIC ENERGY COMMISSION

\section{OFFICES AND LABORATORIES}

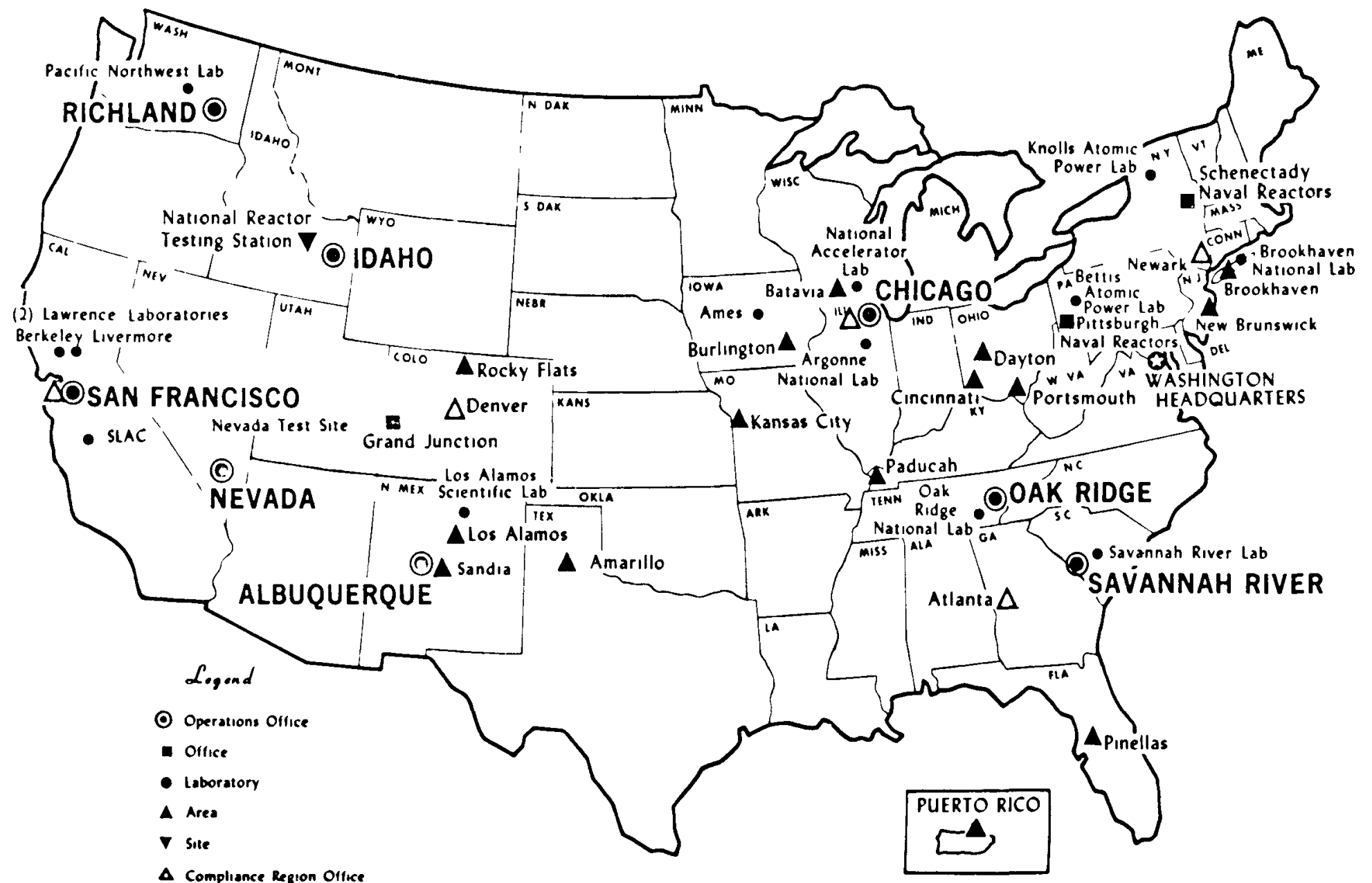




\section{NUCLEAR POWER REACTORS IN THE UNITED STATES}

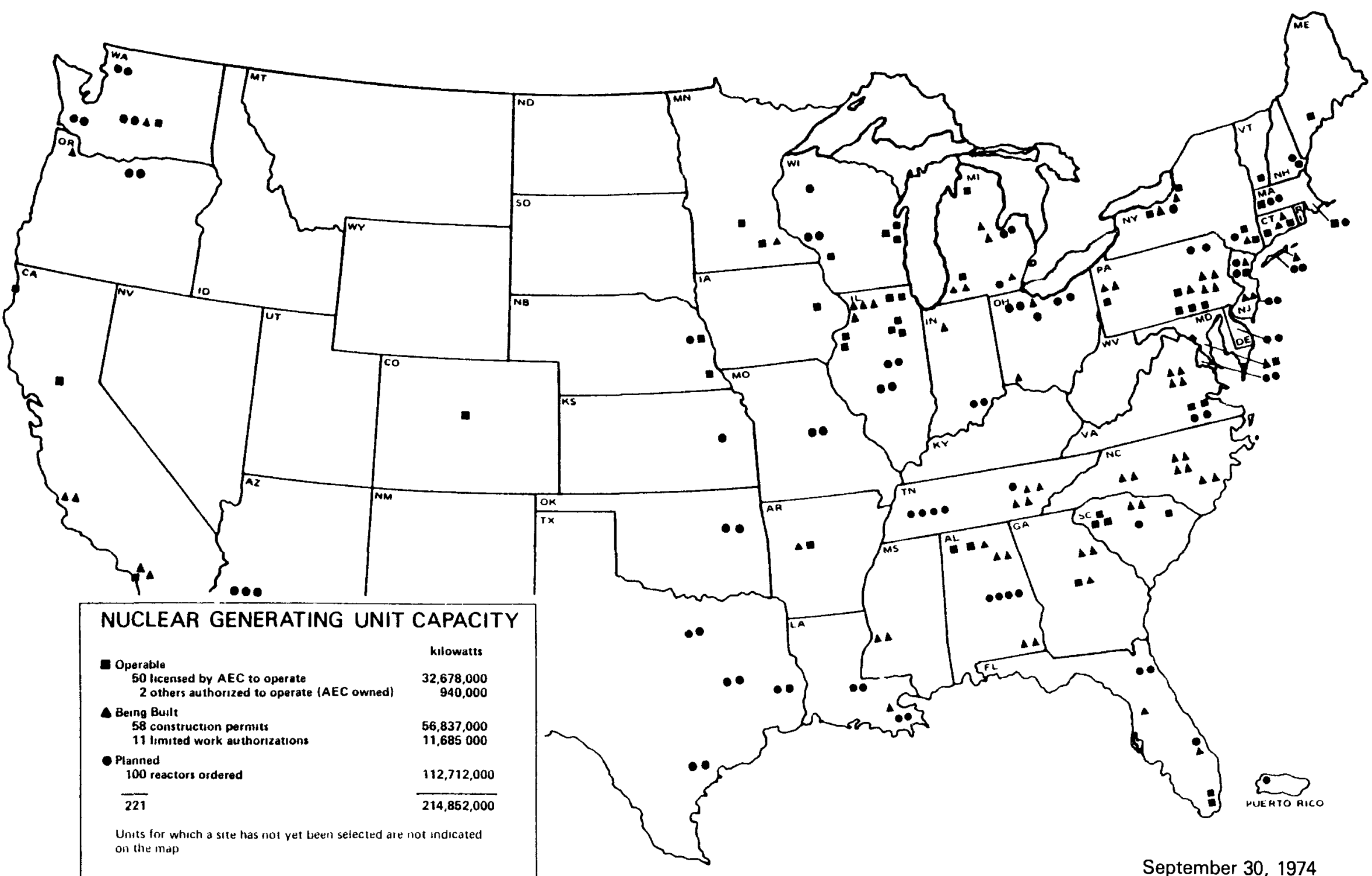




\section{APPENDIX V \\ United States Announced Nuclear Detonations and Early Stockpile Data}

$1945 \cdot 1974$

\begin{tabular}{|c|c|c|}
\hline Event or Series Name & Description & Dates \\
\hline Trinity & $\begin{array}{l}\text { First test of an atomic } \ldots \\
\text { bomb }\end{array}$ & July 16,1945 \\
\hline liroshima $\ldots \ldots \ldots \ldots$ & First use in combat. ..... & August 6,1945 \\
\hline lagasaki ..... & Second use in combat... & August 9,1945 \\
\hline ross & 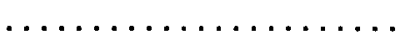 & June - July 1946 \\
\hline & & April - May 1948 \\
\hline $\begin{array}{l}\text { Ranger .......... } \\
\text { Greenhouse ... }\end{array}$ & & January - February 1951 \\
\hline Buster-Jangle.... & & October - November 1951 \\
\hline Tumbler-Snapper & & April - June 1952 \\
\hline Ivy $\ldots \ldots \ldots \ldots$ & & October - November 1952 \\
\hline & $\begin{array}{l}\text { Mike, experimental...... } \\
\text { thermonuclear device }\end{array}$ & October 31, 1952 \\
\hline Upshot-Knothole & $\cdots \cdots \cdots \cdots \cdots$ & March - June 1953 \\
\hline & 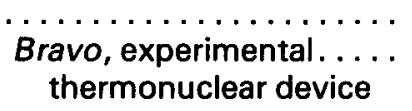 & $\begin{array}{l}\text { February - May } 1954 \\
\text { February 28, } 1954\end{array}$ \\
\hline Teapot & 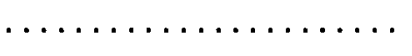 & February - May 1955 \\
\hline & & May 14,1955 \\
\hline Redwing . & & May - July 1956 \\
\hline lumbbob. & & May - October 1957 \\
\hline irgus .. & & $\begin{array}{l}\text { April - August } 1958 \\
\text { August - September } 1958\end{array}$ \\
\hline ardtack......... & & September - October 1958 \\
\hline
\end{tabular}

NO TESTS CONDUCTED FROM OCTOBER 30, 1958 to SEPTEMBER 1961

Nougat

September 1961 - June

1962

Dominic I ........................... April 1962 - June 1962

Storax........................ July 1962 - June 1963

Sedan, excavation ...... July 6,1962

experiment

Dominic II .......... Three above ground tests. July 1962

LIMITED TEST BAND TREATY, AUG. 5, 1963, PROHIBITED NUCLEAR DETONATIONS IN ATMOSPHERE, OUTER SPACE AND UNDER WATER

Niblick

August 1963 - June 1964

Whietstone

July 1964 - June 1965

Flintlock

July 1965 - June 1966

Latchkey

July 1966 - June 1967

Crosstie.

July 1967 - June 1968

Bowline.

July 1968 - June 1969

Mandrel

July 1969 - June 1970

Emery

October 1970 - June 1971

Grommet

July 1971 - May 1972

Toggle.

July 1972 - June 1973

Arbor.

October 1973 - June 1974

Bedrock

July 1974 . 


\title{
Total Announced Detonations by Year
}
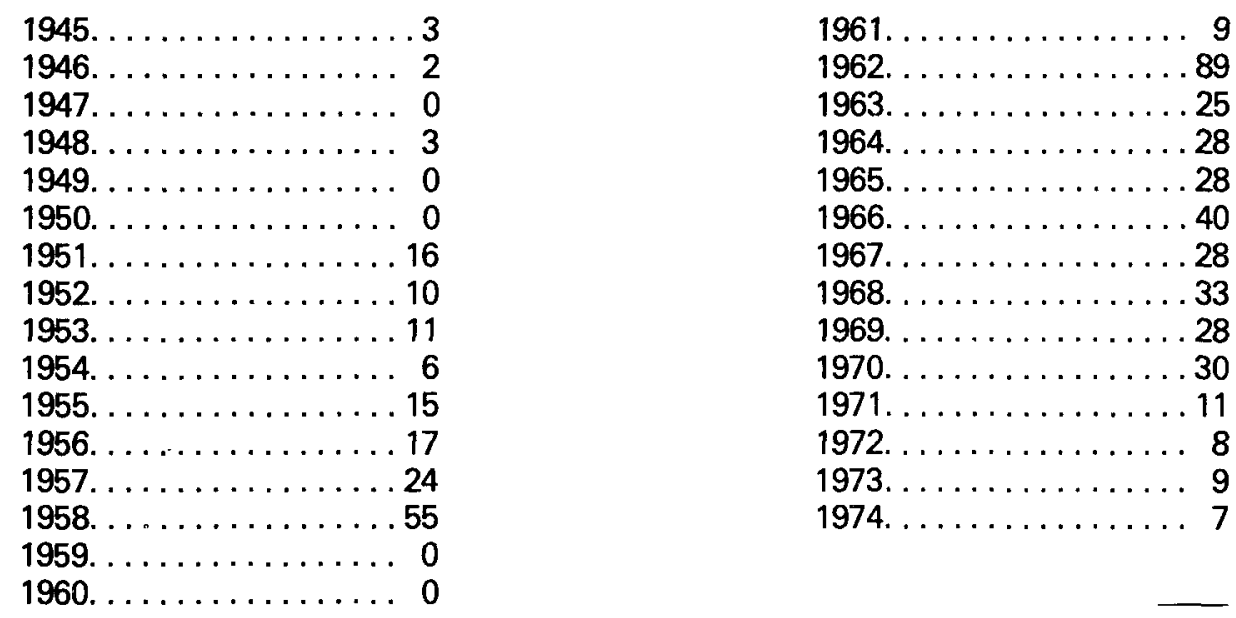

TOTAL

535

\section{Early Nuclear Weapon Stockpile Data}

\author{
Fiscal Year \\ $\begin{array}{llll}1945 & 1946 & 1947 & 1948\end{array}$
}

Number of nonnuclear components

1. Gun-type

2. Implosion-type

0

0

$0^{*} \quad 2^{*}$

2

9

$29 *$

$2^{*}$
$53^{*}$

Number of nuclear components

3. Gun-type

4. Implosion-type

0

0

$0 \quad 0$

2

13

50

*Numbers declassified in 1976 


\title{
APPENDIX VI
}

Financial Statistics

\section{U.S. Government Investment in the Atomic Energy Program}

\author{
(From June 1940 Through January 18, 1975)
}

\begin{abstract}
Appropriation Expenditures:
National Defense Research Council . . . . . . . . . . . . . . . . . . .

Office of Scientific Research and Development . . . . . . . . . . . . . . .

War Department (including Manhattan Engineer District) .

$\ldots \ldots \ldots \ldots \ldots$

Atomic Energy Commission:

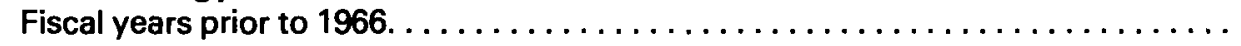

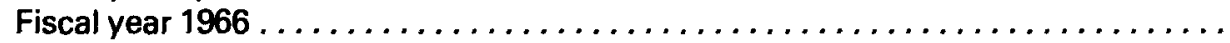

Fiscal year $1967 \ldots \ldots \ldots \ldots \ldots \ldots \ldots \ldots \ldots \ldots \ldots \ldots \ldots \ldots \ldots \ldots$

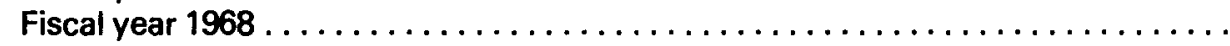

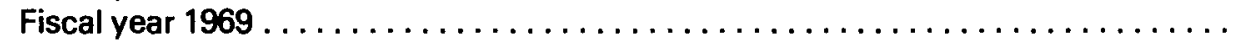

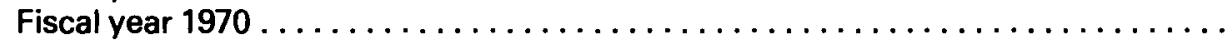

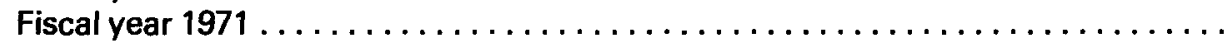

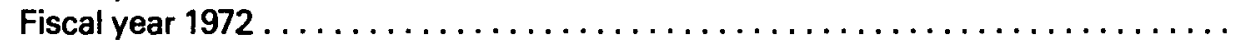

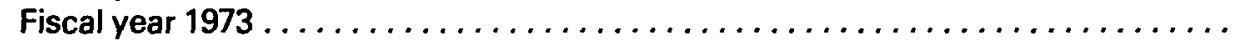

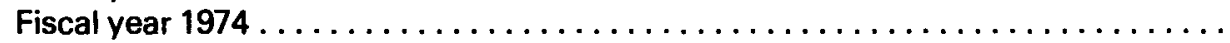

Fiscal Year 1975 (through January 18$) \ldots \ldots \ldots \ldots \ldots \ldots \ldots \ldots \ldots \ldots$

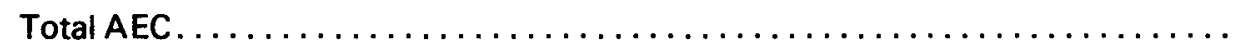

Total Appropriation Expenditures $\ldots \ldots \ldots \ldots \ldots \ldots \ldots \ldots \ldots \ldots$

Unexpended Balance of Funds in U.S. Treasury

January 18, 1975

Total Funds Appropriated

Less:

Collections paid to U.S. Treasury . . . . . . . . . . . . . . . . . . . .

Property and services transferred to other Federal agencies without reimbursement, net of such transfers received

from other Federal agencies. . . . . . . . . . . . . . . . . . . . . . .

Cost of operations from June 1940 through January 18, 1975.

AEC Equity at January 18, 1975 as shown on Balance Sheet (in milkions)

$\$ \quad .5$

14.6

$2,218.3$

$2,233.4$

$34,643.8$

$2,402.9$

2,263.7

$2,466.6$

$2,450.4$

2,455.0

2,274.7

2,392.1

2,393.1

$2,307.5$

$1,512.6$

$57,562.4$

$59,795.8$

$3,439.9$

$63,235.7$

58.0

462.0

$46,562.2$

$\$ 16,153.5$ 
Institutional Origins of the Department of Energy

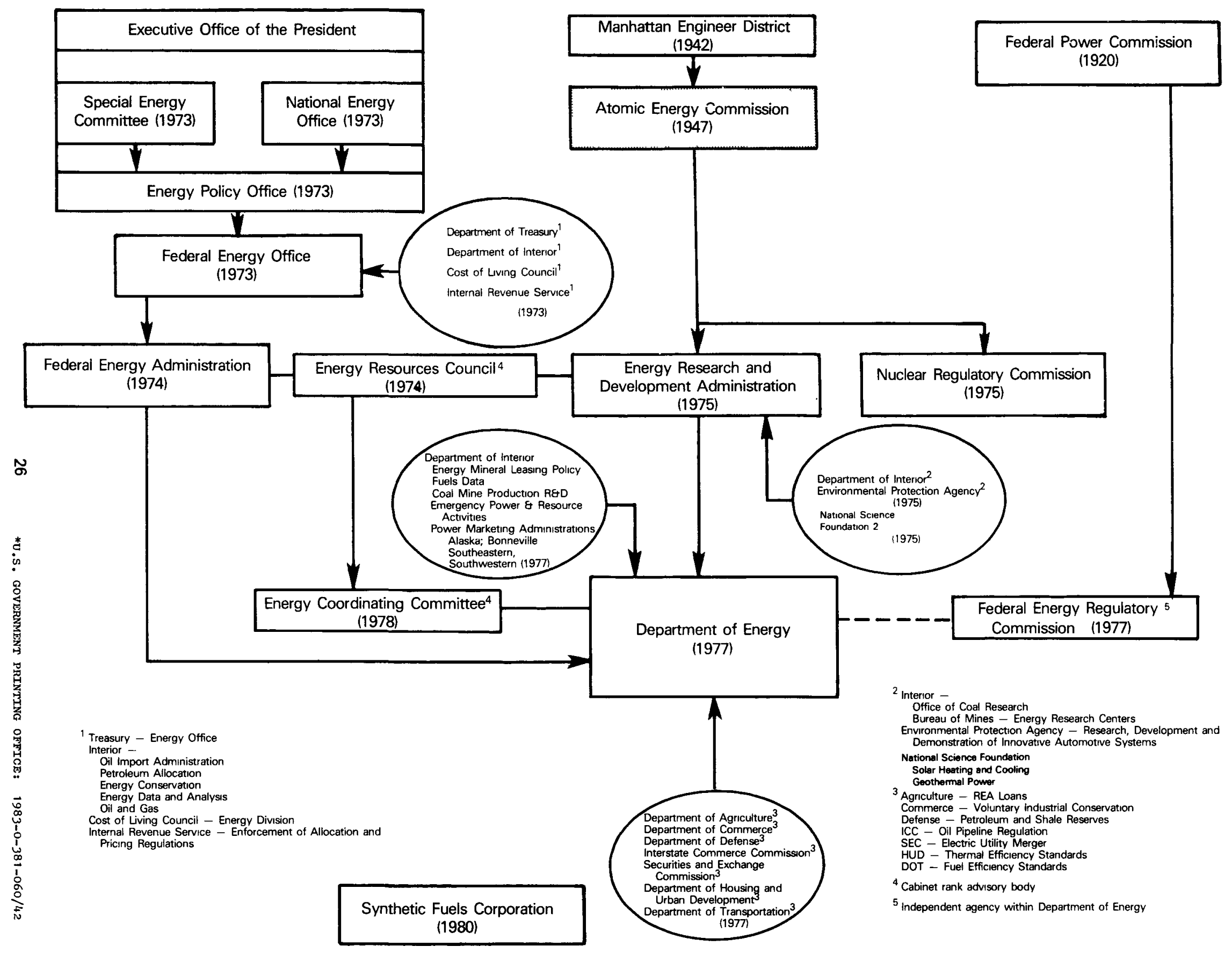

